NBER WORKING PAPER SERIES

HOW CONSTRAINING ARE LIMITS TO ARBITRAGE? EVIDENCE FROM A RECENT FINANCIAL INNOVATION

\author{
Alexander Ljungqvist \\ Wenlan Qian \\ Working Paper 19834 \\ http://www.nber.org/papers/w19834
NATIONAL BUREAU OF ECONOMIC RESEARCH
1050 Massachusetts Avenue
Cambridge, MA 02138
January 2014

We are grateful to Alon Brav and Stephen Figlewski as well as to seminar participants at NUS, NTU, and SMU for helpful comments. We thank Zhou Li and Weibiao Xu for excellent research assistance. Ljungqvist gratefully acknowledges the generous hospitality of NUS Business School while working on this project. All data used in this research come from publicly available sources. The views expressed herein are those of the authors and do not necessarily reflect the views of the National Bureau of Economic Research.

NBER working papers are circulated for discussion and comment purposes. They have not been peerreviewed or been subject to the review by the NBER Board of Directors that accompanies official NBER publications.

(C) 2014 by Alexander Ljungqvist and Wenlan Qian. All rights reserved. Short sections of text, not to exceed two paragraphs, may be quoted without explicit permission provided that full credit, including (C) notice, is given to the source. 
How Constraining Are Limits to Arbitrage? Evidence from a Recent Financial Innovation Alexander Ljungqvist and Wenlan Qian

NBER Working Paper No. 19834

January 2014

JEL No. G02,G12,G14,G23

\begin{abstract}
$\underline{\text { ABSTRACT }}$
Limits to arbitrage play a central role in behavioral finance. They are thought to interfere with arbitrage processes so that security prices can deviate from true values for extended periods of time. We describe a recent financial innovation that allows limits to arbitrage to be sidestepped, and overvaluation thereby to be corrected, even in settings characterized by extreme costs of information discovery and severe short-sale constraints. We report evidence of shallow-pocketed "arbitrageurs" expending considerable resources to identify overvalued companies and profitably correcting overpricing. The innovation that allows the arbitrageurs to sidestep limits to arbitrage involves credibly revealing their information to the market, in an effort to induce long investors to sell so that prices fall. This simple but apparently effective way around the limits suggests that limits to arbitrage may not always be as constraining as sometimes assumed.
\end{abstract}

\author{
Alexander Ljungqvist \\ Stern School of Business \\ New York University \\ 44 West Fourth Street, \#9-160 \\ New York, NY 10012 \\ and NBER \\ aljungqv@stern.nyu.edu \\ Wenlan Qian \\ National University of Singapore \\ Business School \\ Department of Finance \\ Singapore 119245 \\ wenlan.qian@nus.edu.sg
}


Those who believe that stock prices can deviate from true values for extended periods of time routinely appeal to the notion of "limits to arbitrage". After all, as Friedman (1953) argues, without constraints on arbitrage, rational investors should sell stocks that are overvalued, or buy those that are undervalued, until prices return to fundamentals. However, real-world arbitrage is both risky and costly, which introduces frictions in the arbitrage process that can cause mispricing to persist (Harrison and Kreps (1978)). Without these frictions, behavioral finance would not be possible (Brav, Heaton, and Rosenberg (2004)).

In their survey of behavioral finance, Barberis and Thaler (2003) list three sources of frictions which contribute to limits to arbitrage:

1. Fundamental risk: in the absence of perfect substitutes for the mispriced security, riskfree portfolios cannot be constructed and so arbitrage is risky;

2. Implementation costs (D’Avolio (2002), Gromb and Vayanos (2002), Lamont and Thaler (2003), Jones and Lamont (2002), Nagel (2005), and others): these include the costs of discovering a mispriced security, the costs of the resources needed to exploit a mispricing, transactions costs (commissions, bid-ask spreads, price impact), and short-sale constraints (margin requirements, lending fees, legal constraints preventing some investors from going short or from lending their stock to others);

3. Noise trader risk (DeLong et al. (1990)): in the short run, mispricing could get worse, forcing early liquidation of a position at a loss. As Shleifer and Vishny (1997) note, this can make it hard for arbitrageurs to persuade investors to finance their bets against mispricing: whenever a bet loses money, investors cannot tell whether the arbitrageur was wrong or whether prices moved even further from fundamentals. This fundamental uncertainty limits the capital available to arbitrageurs.

In this paper, we ask a simple question: How constraining are limits to arbitrage empirically? We 
address this question by studying a recent financial innovation designed to sidestep limits to (risky) arbitrage. The innovation involves a set of "arbitrageurs" in the Shleifer-Vishny (1997) mold who are constrained in their ability to raise capital from investors and therefore shallowpocketed. The arbitrageurs expend considerable resources identifying overvalued companies and then risk (mostly) their own limited capital trading against these companies, despite high noise trader risk and severe short-sale constraints in the form of exceptionally high lending fees, a highly inelastic supply of shortable stock, and unusually expensive put options.

Our main contribution is to show that even in this uninviting setting, arbitrage can succeed in correcting mispricing. On average, the prices of target companies in our sample fall by $21.9 \%$ over 3 months and by $56.8 \%$ over 12 months, net of market movements. These price corrections are sufficiently large to make arbitrage profitable. We estimate that the arbitrageurs (or "arbs" for short) earn cumulative abnormal profits averaging $18.2 \%$ over three months, net of short-sale fees and risk-adjusted using the three Fama-French factors and momentum. Given that the arbs stay in business, returns of this magnitude (which are not annualized!) are likely large enough to cover the information discovery costs they incur in identifying and investigating their targets.

How do the arbitrageurs sidestep the limits to arbitrage they face? Not by outgunning their targets: the arbs in our sample are individuals or small boutiques with insufficient resources to correct mispricing in the textbook manner of shorting what they believe to be overpriced stocks until prices converge on the true value. Nor do they have the financial wherewithal to stand their ground should noise traders drive prices even further away fundamentals. In other words, the limits to arbitrage are real enough. ${ }^{1}$

But they are apparently easily surmountable. Our evidence shows that the arbs, once they

\footnotetext{
${ }^{1}$ And of course the arbitrage is risky, as the strategy involves a directional bet, albeit a high-conviction one that can be partially hedged against general market movements. We nonetheless refer to the information producers as arbitrageurs rather than as short-sellers, to distinguish them from uninformed short-sellers in the market who might mimic their trades in the spirit of Abreu and Brunnermeier (2002).
} 
have identified an overvalued company, take a short position and then do something we don't usually associate with arbitrageurs: they reveal their information to the market. While their short position is necessarily small - given their own capital constraints, the high shorting fees, and the shortage of shortable stock - it need only be large enough to cover their information discovery costs for arbs to have an incentive to discover mispriced stocks in the first place.

Why reveal the information? The arbs lack the financial firepower by themselves to correct the mispricing through aggressive shorting; and the same short sale constraints the arbs face likely also prevent other short-sellers from driving down the price. Revealing the information publicly is a way to sidestep these capital and short sale constraints. The apparent aim of this financial innovation is to engage the one group of investors who are not constrained: the target company's current shareholders (which we call the "longs”). If the longs can be persuaded to sell, this will not only correct the mispricing but in the process also reduce noise trader risk by accelerating price discovery.

Textbook arbitrage has investors keep their information secret so as not to move prices too quickly: if arbitrage is riskfree, every arbitrage trade is profitable and so the incentive is to keep the arbitrage opportunity both alive and secret for as long as possible. Of course, the very act of arbitrage will sooner or later reveal the arbitrageur's information, through his trades and the price mechanism. The arbitrage process we observe in our setting stands this logic on its head: revealing the information voluntarily and thereby accelerating price discovery reduces the risk of the arbitrage strategy and sidesteps the arbs' limited-resource constraint.

For this strategy to work, it is critical that the information the arbs reveal to the market is credible - or else the longs will ignore it. We observe that the arbs in our sample argue their case by way of highly detailed reports which they post publicly and for free. Compared to reports published by sell-side equity analysts at investment banks, which have a tendency to be both 
optimistic and biased, the arbs' reports tend to focus on questionable governance practices and aggressive accounting (sometimes alleging fraud) and contain much more by way of new facts, often assembled with the help of forensic accountants and professional investigators. ${ }^{2}$ To make their case, the arbs include many "smoking guns," in the form of recorded phone conversations, video surveillance, photographs, etc.

We find that investors appear to listen. Volatility spikes up by $270 \%$ on average the day the arbs post their reports, as market participants process the information. Turnover spikes by even more, up by $366 \%$, and liquidity improves in its wake, up by $181 \%$. At the same time, prices fall by $8.18 \%$ on average on the release day and then continue to drift lower over time.

Very little of the price pressure comes from the short side of the market. While we see evidence of the arbs building significant (albeit relatively small) short positions before releasing their reports, once the reports are out, there is no further abnormal shorting activity. This reflects a dramatic worsening in short sale constraints: the cost of initiating new shorts jumps by $52 \%$ on average when a report is released, putting it in the 81st percentile of the distribution of all stocks in CRSP. Over the next three months, the cost continues to climb, reaching the 90th percentile (up by a total of $238 \%$ compared to the pre-release period). At the same time, the supply of lendable stock available for borrowing falls and put options become unusually expensive.

The price falls instead come about because of the trading behavior of the one group of investors who are unconstrained: investors with long positions in the targets. We find that turnover involving longs spikes by $415 \%$ on average when the arbs release their reports.

Subsequent events usually prove the arbs factually right. For example, $35 \%$ of targets are subsequently delisted, 38\% replace their auditors or see their auditors resign, and $23 \%$ restate

\footnotetext{
2 Prominent examples include Muddy Waters’ June 2011 report on Sino-Forest, a Chinese company listed in Toronto which a year later went bankrupt, and Citron Research’s January 2011 report on China MediaExpress, a Chinese company delisted from Nasdaq six weeks later. Around half of the companies in our sample are Chinese firms listed in the U.S.; the other half are American.
} 
earnings. In fact, in only $19 \%$ of cases do subsequent investigations by the SEC, the Department of Justice, or a stock exchange disprove the alleged facts contained in the reports. This is remarkable given that our sample is unbiased: we have a complete, ex ante list of target companies, rather than a self-reported selected list of only those that made money for the arbs.

Our sample covers 17 arbs who between July 2006 (when daily short-sale data first become available from DataExplorers) and December 2011 target 113 U.S. listed companies. We have a total of 332 reports (around three per company on average), as some arbs post follow-up reports with more information or in response to management and because other arbs sometimes post reports of their own. The arbs are either individuals or small firms that trade for their own account. The fact that they have short positions which will appreciate in value if the price falls is prominently disclosed in the reports.

Clearly, reports should only induce the longs to sell if the information they contain is credible. When we condition investors' responses on an arb’s track record, we find that only arbs with a history of making claims that are subsequently confirmed are able to induce the longs to sell and thereby put pressure on a target's share price. And it is only credible reports that generate profits for the arbs, net of shorting fees: without credibility, prices do not fall significantly. This supports the mechanism we propose to sidestep the limits to arbitrage.

Credibility matters, but not absolutely: to be listened to, an arb also has to have something new to say. We show that reports that present new facts previously unknown to investors (e.g., resulting from on-the-ground detective work) result in longs selling and rapid price corrections whereas reports that merely reinterpret known data do not. As a result, only reports that contain “scoops” generate significant profits for the arbs. This too supports our proposed mechanism.

Our paper primarily contributes to the behavioral finance and asset pricing literatures by showing that limits to arbitrage may not always be as constraining as sometimes assumed. Even 
though the arbs in our sample target only a relatively small number of companies, our evidence shows that limits to arbitrage can be sidestepped using the innovative arbitrage mechanism we describe. The innovation involves credibly convincing investors that the target truly is overvalued. While the primary audience for this message is the longs, without whom prices would presumably not adjust (or at least not sufficiently quickly), a reputation for credibly identifying overvalued companies might eventually allow some arbs to raise funds from institutional and other investors. This would help overcome the limit to arbitrage identified by Shleifer and Vishny (1997): the inability to persuade other investors to commit capital to an investment strategy aimed at correcting mispricing.

In addition, our paper also contributes to the growing literature on the role of short sellers in producing and transmitting information in capital markets. There is little prior evidence on what short sellers know and how they acquire information. Our unique data allow us to observe the information discovery process at the level of individual information producers and to study how the information the arbs discover is then incorporated in security prices. ${ }^{3}$

The paper proceeds as follows. Section 1 presents our sample. Section 2 gives a flavor of the lengths to which the arbs go to discover mispricing and the resulting richness of the data they assemble for their reports. Section 3 documents the market's reaction to the release of these data and the ensuing price correction. Section 4 attempts to pinpoint the mechanism by conditioning the market's reaction on the credibility of the arb and the content of the report. It also shows that arbs make money - and prices are corrected - in even the hardest-to-short target stocks for which limits to arbitrage would be expected to be the most severe. Section 5 concludes.

\footnotetext{
${ }^{3}$ Previous research on short sales finds that they predict lower subsequent returns (Figlewski (1981), Desai et al. (2002), Cohen, Diether, and Malloy (2007), Boehmer, Jones, and Zhang (2008), Diether, Lee, and Werner (2009)), target overvalued firms (Dechow et al. (2001), Hirshleifer, Teoh, and Yu (2011)), and often precede negative corporate events such as negative earnings announcements, analyst downgrades, or financial misconduct (Christophe, Ferri, and Angel (2004), Desai, Krishnamurthy, and Venkataraman (2006), Christophe, Ferri, and Hsieh (2010), Karpoff and Lou (2010)), though Engelberg, Reed, and Riggenberg (2012) find short sellers are more likely to trade after corporate events.
} 


\section{Sample and Data}

\subsection{Arbitrageurs and Reports}

The arbitrage strategy we describe relies on publicity to generate a return on information production, so identifying the relevant "arbitrageurs” is relatively straightforward. Our sample consists of all arbs who research companies, take short positions, and initiate coverage on at least two U.S. listed target companies over our sample period (July 2006 to December 2011). Table 1 lists the 17 arbs in our sample. The pioneer is Manuel Asensio of Asensio \& Co., which was founded in 1992 and started publishing reports on overvalued companies in 1994. The most prolific arb in our sample is Citron Research, which has been in business since 2001 and which describes itself as an "activist short seller.” A firm that has come to prominence in the media is Muddy Waters, which describes itself as a "pioneer in on-the-ground, freely published investment research.”

Because private firms in the U.S. do not generally have to make public disclosures, we are unable to provide summary statistics on the 17 arbs. Inspection of their websites suggests that they are either one-man-bands or small firms. Except for Kerrisdale, Bronte Capital, and Asensio \& Co., none of the arbs currently is, or has ever been, registered as an investment adviser or broker-dealer with the SEC or FINRA, suggesting that the arbs generally do not manage money on behalf of external clients (at least not in the U.S.). All, however, take short positions in the companies they target.

From the arbs’ websites, we download all 374 reports the arbs have published since July 2006 (when DataExplorers first makes daily shorting data available). ${ }^{4}$ We ignore reports published after December 2011, so that we have at least a year of post-report share prices in

\footnotetext{
${ }^{4}$ Three of the arbs (Kerrisdale, Absaroka, and OLP Global) restrict access to their websites to clients only while at the same time making their reports publicly available via prominent third-party websites such as seekingalpha.com. Four of the arbs (Chimin Sang, Ian Bezek, Shareholder Watchdog, and The Forensic Factor) do not have websites of their own and disseminate their research solely via third-party websites. All our results are qualitatively unchanged if we exclude these four arbs from the sample.
} 
CRSP to identify price corrections and measure the arbs' trading profitability. To check how comprehensive our list of reports is, we use the Internet Archive (also known as the Wayback Machine), which stores historical web pages. We find no instance of an arb removing any reports, whether inconvenient or otherwise. In this sense, our set of reports is both comprehensive and unbiased. We remove 30 reports on firms that are traded over-the-counter or on the Pink Sheets (for which we have no share price or other trading data) and 12 reports on firms that are listed outside the U.S. (for which we have no short selling data; this filter removes perhaps the most famous target firm, Sino-Forest, which was listed in Toronto). This leaves us with a set of 332 reports.

The average arb publishes 20 reports over our sample period. As Table 1 shows, Citron Research accounts for 106 of the reports, followed by Alfred Little with 37 reports, and Asensio \& Co. with 34 reports.

In total, the arbs target 113 U.S.-listed companies between them over our sample period. This means there are 2.9 reports per company on average. Of the 332 reports, 118 are "first” reports in which a company is targeted by one of the arbs for the first time. (In five cases, two arbs initiated coverage of the same company on the same day.) The remaining 214 are follow-on reports by the same or another arb. Citron Research publishes the most first reports, 43, followed by Bronte Capital at 10. Given its longer history, Citron also covers the largest number of targets, at 46. (All our results are qualitatively unchanged if we exclude Citron from the sample.)

To dispel the notion that the patterns we document are driven by Chinese companies listed in the U.S., which have received bad press over the last few years, we note that far from all sample companies are Chinese: 58 of the 113 companies come from China (51.3\% of the sample) and the remaining 55 come from the U.S. (48.7\%). All our results are qualitatively unchanged if we 
exclude Chinese targets from the sample. ${ }^{5}$

For each target firm in our sample, we know the arb who first targeted it and the exact date of each report. (We describe the target companies in Section 1.3 and the contents of the reports in Section 2.) We also hand collect information on material events before and after a report is released from SEC filings such as 10-Ks, 10-Qs, and 8-Ks and from Factiva. This gives us a complete timeline of all material events surrounding the reports through December 2012.

Table 1 reports, for each of the 17 arbs, summary statistics for abnormal share price returns on the day a company first becomes a target, cumulative abnormal returns from the report date to 60 trading days later, and the arb’s profit (net of market movements and shorting fees and assuming that the arb initiates his short position five days before releasing a report which is then marked-to-market on a daily basis for the next three months). ${ }^{6}$

For 15 of the 17 arbs, share prices fall on average when coverage is initiated on a target. Chimin Sang has the largest immediate market impact, averaging $-19.9 \%$, followed by Alfred Little at $-19.2 \%$ and Muddy Waters at $-18.0 \%$. The average arb averages an $8.5 \%$ price.

Measured over the three months after initiation, 14 of the 17 arbs see prices fall even further (adjusted for the three Fama-French factors and momentum). Over this timeframe, Asensio \& Co. has the largest price correction, averaging -58.9\%, followed by Absaroka Capital Management at $-54.1 \%$ and GeoInvesting at $-39.8 \%$. For the average arb, prices fall by $18.6 \%$ on average in the three months following the release of a first report. Only three arbs see prices move against them on average over this timeframe.

As an estimate of the arbs' profitability, Table 1 reports estimates of the returns to a markedto-market borrow-and-hold strategy that shorts the target stock five days before the report day

\footnotetext{
${ }^{5}$ This mirrors Lee et al.'s (2013) conclusion that U.S. listed Chinese firms as a group do not differ much from their U.S. counterparts, despite the bad press a minority of them have received.

${ }^{6}$ Results are not sensitive to this assumption, as we will see later.
} 
and closes out the short position three months after the report is released. The returns are net of shorting costs and risk-adjusted using the three Fama-French factors and momentum. (For all variable definitions and details of their construction, see Appendix A.) By this measure, Asensio \& Co.'s reports yield the highest returns, averaging 61\% over three months (not annualized), followed by Absaroka Capital Management at 51.8\% and GeoInvesting at 40.4\%. For the average arb, our borrow-and-hold strategy yields an average three-month return of $18.9 \%$.

\subsection{Other Data Sources}

We obtain equity lending data from DataExplorers, a research company that collects stock and bond lending data directly from the security lending desks at the world's leading financial institutions. The database contains comprehensive information on the supply of shares available for borrowing, the number of shares out on loan, and loan fees for over $85 \%$ of the global equity lending market (though our subscription only covers the U.S. market). A detailed description of the equity lending data can be found in Saffi and Sigurdsson (2011) and Jain et al. (2012). Following convention, we proxy for actual short selling using shares out on loan. ${ }^{7}$ Daily shorting data are available from July 2006, which thus defines the beginning of our sample period.

Daily price and trading data for the target companies are obtained from CRSP, accounting data from Compustat, intra-day price data from TAQ, and option data from OptionMetrics.

\subsection{Target Companies}

Table 2 characterizes the 113 target companies by providing a snapshot of firm characteristics and shorting conditions as of one month before the release of the first report. At that point in time, the average target has a market capitalization of $\$ 979.2$ million, putting it in the 54th percentile of the distribution of CRSP firms. It has a book-to-market ratio of 0.4 (equal to the 30th percentile) and so comes from the growth part of the value-growth spectrum. Its daily

\footnotetext{
${ }^{7}$ During our sample, naked short selling is generally discouraged and short selling must be associated with stock borrowing, suggesting that the number of shares out on loan is a good indicator for actual short selling.
} 
share turnover of $2.35 \%$ of shares outstanding puts it in the right tail of the CRSP distribution (71st percentile). It is relatively liquid, with an Amihud (2002) illiquidity measure of 0.04 (43rd percentile). Its stock returns are unusually volatile, with a monthly standard deviation of $7.44 \%$ (78th percentile).

How easy would it be to short these companies' stock? As Table 2 shows, it would be expensive: one month before the first report is released, the average target company has a shorting fee of 4 basis points a day (10.6\% annualized), which is in the right tail of the CRSP distribution (76th percentile). This reflects an unusually tight supply of lendable stock: on average, only $4.85 \%$ of shares outstanding are available for borrowing (39th percentile). Putting downward pressure on a target's share price via the options market would also be difficult, as its put options are unusually expensive: the ratio of the implied volatility of puts to the implied volatility of calls on the target's shares averages 1.15 (69th percentile). Absent short sale constraints, the ratio would equal one.

In sum, targets are growth companies of average size whose shares are heavily traded and quite liquid. But they are also hard to arbitrage, as lending fees are high, lendable stock is tight, and put options are pricey. And yet, as we will show, arbitrageurs manage to systematically correct mispricing in spite of these limits to arbitrage.

\section{Discovering Mispricing}

Figure A1 in the Appendix shows the cover pages of three representative reports in our sample. In some ways, the reports resemble equity research notes written by sell-side research analysts working for investment banks, but there are three important differences: 1) the arbs typically go to a lot of trouble to uncover mispricing; 2) they consistently issue "strong sell” recommendations (whereas sell-side analysts have a tendency to issue "buy" or "strong buy" recommendations); and 3) they (legally) front-run the publication of their reports by taking short 
positions in the target stocks.

All sample reports claim the target's stock is overpriced, but they differ in the grounds for their claims. Cases range from aggressive accounting that obscures the firm's true value to outright fraud. Based on a careful reading of the reports, we divide the sample into those reports that convey the results of information production (i.e., the discovery of facts previously unknown to investors) and those that result from information processing (i.e., the reinterpretation of already known data). In this section, we aim to give a flavor of the lengths to which the arbs go to discover mispricing and the resulting richness of the data they assemble for their reports.

\subsection{Information Production}

The vast majority of the reports (285 of 332) reveal new information. Panel A of Table 3 tabulates the kinds of new information they contain. We distinguish between concerns regarding financial reporting (such as accounting irregularities or misleading disclosure) and questionable corporate governance practices (such as forgivable loans to executives) on the one hand, and concerns that arise from "red flag” events (such as suspicious acquisitions, self-dealing, undisclosed related-party transactions, and questionable insider trades) on the other hand.

Since we only observe the targets that the arbs choose to report on, we cannot say how they chose these targets in the first place. But there are some telltale signs. In each case, the arbs pick up suspicious signals from publicly observable information that the market, arguably, had simply missed or misinterpreted. Several targets caught the arbs' attention due to unusual patterns of behavior (for example, constantly raising equity from shareholders while claiming to have large unused cash balances) or implausible, too-good-to-be-true margins. The following example illustrates the latter:

"[The company] boasts an unjustifiable $40 \%+$ gross margin in the domestic business and reports operating margins $46 \%$ higher than its strongest competitor, which is over $8 x$ its size. With all of the major competitors being much larger publicly traded companies with manufacturing facilities and cost structure similar or superior, I see no validity to the Company's explanation of its high margins due to its 
purportedly lower cost base and greater economy of scale."

Other telltale signs include the individuals behind the firms. Some Chinese target firms, for example, used the services of a particular "promoter" to obtain a listing in the U.S., and once some of the promoter's companies became involved in regulatory investigations, his other clients also came into the arbs’ crosshairs. In other cases, target firms shared a little known boutique auditor that had become the subject of an investigation by the Public Company Accounting Oversight Board for violating quality control and auditing standards.

Once they have identified a potential target, the arbs follow up with in-depth investigations that go well beyond what sell-side equity analysts typically engage in. Investigations may start with an extensive document review, not only of existing filings and public records but also of non-public or difficult-to-access documents such as purchase agreements, customer orders, original auditor reports, tax returns, or the filings and documents of competitors. (A favorite, in the context of Chinese companies listed in the U.S., is a comparison of Chinese-language filings with local regulators and English-language filings with the SEC, which often reveals aggressive accounting that flatters the company’s U.S. earnings.)

In a process that can take many months, investigations often involve poking holes in claims the target made in public disclosures (such as SEC filings) or conference calls. To this end, arbs may contact target firms’ management to clarify doubts (and record the conversations); consult industry experts for independent opinions; arrange authorized or unauthorized site visits, accompanied by industry experts or private investigators; or put a target's production facilities under video surveillance. To illustrate,

"Our on-site due diligence confirmed our thesis that the company is nowhere near the scale that it claims to be. On our visit, we saw a very small operation that appeared to be formerly government owned, and probably privatized for very little money. [The company] claims to have six legacy paper production lines, but despite our prior agreement to see all lines, it showed us only two. [...] The equipment is clearly dated ...” 
Arbs may also visit a target's distribution channels and customers to gauge the reliability and strength of its revenue prospects, or contact the target's business partners and competitors to verify specific claims made by the target. For example, one arb conducted an extensive 10-city, 60-store channel check:

"[T]he investigators were instructed to count the number of small kitchen appliance brands, note the prices each brand was selling for, and ask the store/department managers and at least two different sales clerks a short list of questions about their experience selling products manufactured by the company and its competitors. For purpose of verification, the investigators were also instructed to record the name, address, phone \# of the stores, as well as the name and cell phone \# of the managers they spoke to."

This particular channel check revealed that the target's sales were suspiciously slow given the firm’s reported revenue growth. More generally, investigations can uncover falsely-reported revenue or non-existent or suspicious customers.

Once an investigation is completed, the evidence is assembled into a highly detailed report that is subsequently disclosed to the investing public. To attract investors' attention, the reports often have catchy titles such as "Credibility is like virginity; once you lose it, you can never get it back.” (See Table A1 in the Appendix for further examples.)

In an effort to be convincing, the reports include in-depth coverage of the issues identified during the investigation, often supplemented with scanned copies of original company documents, photos (of production facilities or distribution channels), and links to videos taken during site visits and audio recordings of conversations with target executives. (See Figure A2 in the Appendix for examples.) In several cases, reports provide "smoking gun" evidence in the form of audio clips of employees admitting misrepresentation, video clips contradicting production claims, and irreconcilable discrepancies between foreign and U.S. filings. One particularly egregious example involves evidence of fraud; the target was subsequently investigated by the SEC:

"We recorded a telephone conversation that contains an admission that [the company] is engaging in securities fraud." 
The costs and risks of this information discovery process are not trivial. Besides the difficulty of obtaining evidence to support their suspicions, the arbs often face open resistance, and occasionally hands-on obstruction, from target companies. The following example illustrates:

"Surveillance efforts are costly and difficult to conduct under very threatening conditions. [...] Agents first must spend a few weeks watching and evaluating factory operations to determine the production cycle, factory entrances, and security surrounding the facility. The expensive cameras must be hidden so that the company does not find them, typically quite some distance from the factory and requiring use of a good zoom lens. [...] Sometimes the cameras get stolen, in which case a backup camera is always on hand. Each day the local operative replaces the camera batteries (usually in the darkness of night) and memory card. [...] The local operatives [...] have been detained, questioned, and beaten by company security.”

The arbs also face the risk of being sued by their targets. In the words of the Wall Street Journal (June 14, 2006), "What was already a difficult and sometimes gut-wrenching strategy has only gotten harder in recent years. Nowadays, more of the companies that short sellers target are fighting back with lawsuits. They also mount sophisticated public relations campaigns against shorts.” ${ }^{8}$ On a more positive note, the very real risk of lawsuits will, to some extent, keep the arbs from making claims they cannot substantiate. This, in turn, will make it likelier that their reports will be believed.

\subsection{Information Processing}

While most of the 332 reports in our sample reveal new information and rely on hard evidence to make their case, a minority of the reports instead present reinterpretations of already known facts to argue that a target is overvalued. These reports are thus essentially opinions, without new evidence, and so are more similar to "sell" recommendations issued by sell-side research analysts. As such, we might expect them to have little more impact on share prices than sell-side analysts tend to have when they downgrade a stock. ${ }^{9}$ As we will see, our results are consistent with this prediction.

\footnotetext{
${ }^{8}$ See also Lamont (2012) who studies “battles” between short sellers and targets.

${ }^{9}$ Previous research documents abnormal returns averaging around $-4 \%$ in a short window around analyst downgrades to "sell” (Womack (1996), Loh and Stulz (2011)).
} 


\section{Correcting Mispricing}

\subsection{Reaction in the Equity Market}

How does the equity market react when the arbs release their reports to the public? Table 4, Panel A documents the share price reaction to the release of a "first" report targeting a company. On the release day (day 0), prices fall by an average of 8.18\% (adjusted for the three FamaFrench factors and momentum); the median price fall is 5.2\%, and fully 82 of the 113 releases trigger a fall in price. (All three statistics are statistically significant at the $1 \%$ level.) When arbs release follow-on reports on a target, returns are (not surprisingly) lower, averaging 2.59\%, but they remain both economically and statistically significant (see Panel B).

These patterns suggest that the reports contain relevant and novel information which investors take seriously. And investors appear to incorporate the information fairly rapidly. In five cases, we know the exact time of the report release. Figure 1 below shows continuously compounded raw returns over five-minute intervals during the eight trading hours before and after the release of a first report. At least for these five reports, prices fall by more than $10 \%$ within two hours of release.

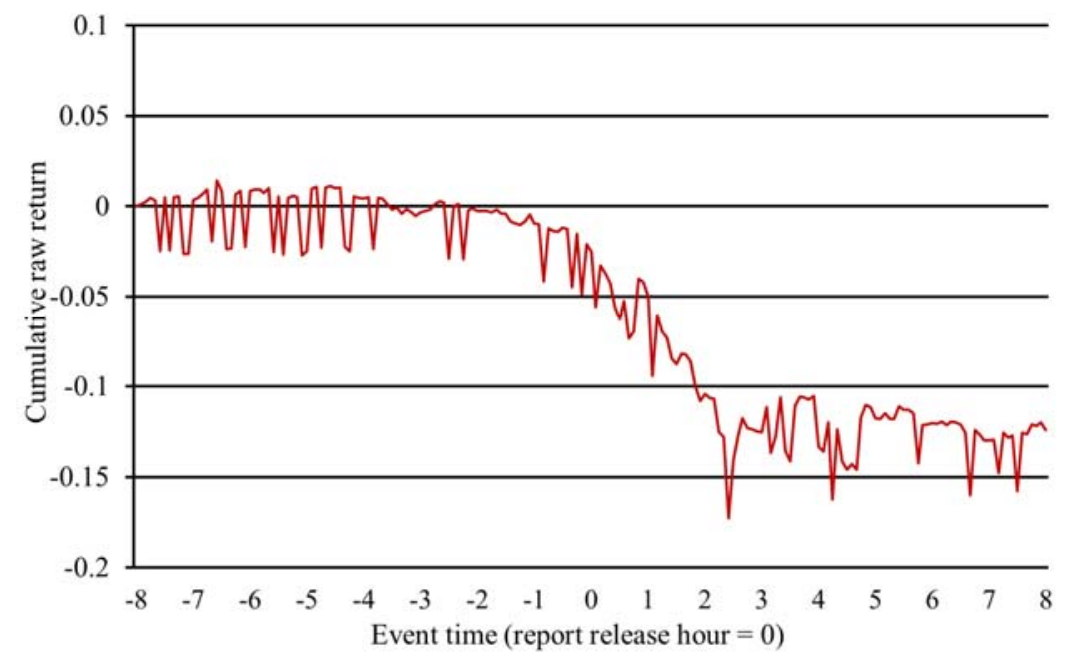

Figure 1. Price Adjustment on the Report Date

Table 4, Panel A reveals two further interesting patterns. First, between trading day -20 and 
trading day -6 , target companies' share prices rise by $4.43 \%$ on average, net of market movements $(p=0.003)$. This suggests that the arbs are not simply trend chasers. In fact, they may be timing the release of their reports to coincide with price run-ups, which would increase the expected profitability of their shorting strategy. Second, there is evidence of a modest pre-event run-down in prices close to the report day: over the week leading up to release, returns fall by $1.31 \%$ net of overall market movements. This is marginally statistically significant $(p=0.082)$ and could suggest that the short positions the arbs build before releasing their information put some moderate pressure on share prices.

The striking difference between the gentle downward drift in the week leading up to the release and the sizeable share price fall once the report becomes available to the public suggests that the arbs are unable to build sufficiently large short positions to correct the mispricing on their own. This is indicative of frictions in the arbitrage process, consistent with the challenging shorting conditions for target stocks seen in Table 2. A natural response to these frictions is for the arbs to release the information publicly and let the current shareholders (i.e., the "longs”) do the work for them. As long as the arbs make enough money, in expectation, on whatever short positions they could afford to build so that they can cover their information production costs, this strategy will encourage information production, and hence price correction, even in cases where limits to arbitrage appear to be binding.

Just how big a shock to investors' information sets the reports represent can be seen in Figure 2 below, which shows that volatility spikes when a report is released: on average, volatility increases by $270 \%$ on the release day, compared to the firm's baseline volatility estimated in a 
three-month window ending 21 trading days before the report day. ${ }^{10}$ The dashed lines, which represent 95\% confidence intervals, indicate that this increase is highly statistically significant. Volatility remains significantly elevated for the next five days, suggesting investors take up to a week to process the information revealed in the average report.

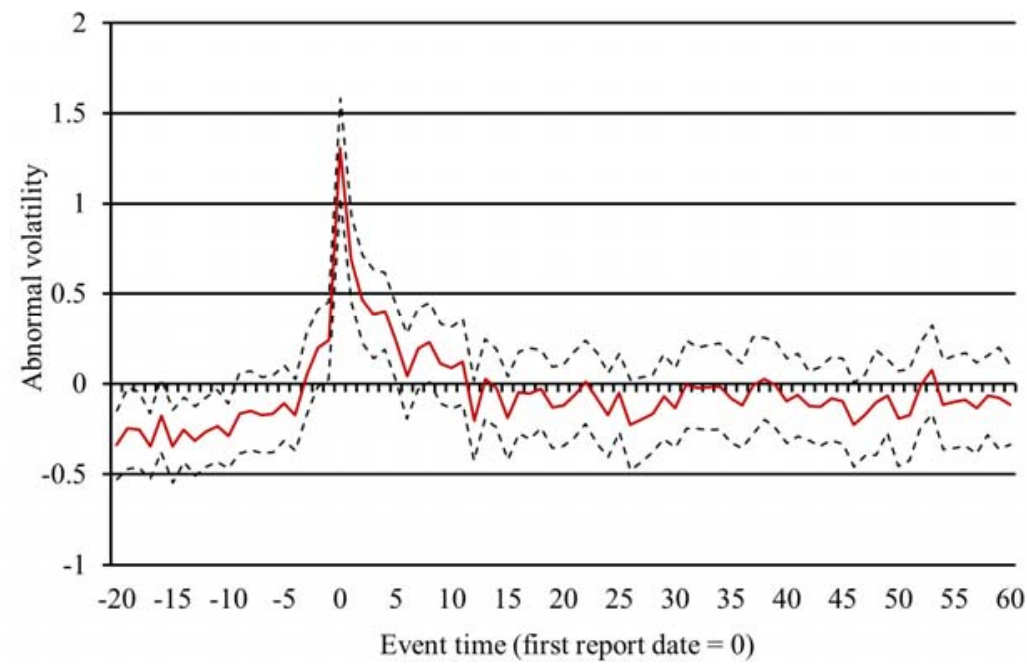

Figure 2. Average Abnormal Volatility

The reports also trigger a massive increase in trading activity. Figure 3 shows that share turnover (i.e., number of shares traded scaled by shares outstanding) begins to rise significantly relative to the baseline around four days before the report day (perhaps because the arbs build their short positions) and then spikes at 366\% above the baseline on the release day (i.e., by $\exp (1.538)-1)$. In dollar terms, this represents a jump from an average baseline turnover of \$18.45 million per day to an average of \$55.57 million on the release day. Turnover stays significantly higher than normal for the next 23 trading days before returning to baseline levels.

\footnotetext{
${ }^{10}$ In this and subsequent figures, we compute percentage changes relative to a baseline estimated over a three-month period ending one month before a report date. Specifically, the "abnormal" value of variable $X$ is computed as the log difference between $X$ on day $t$ and average daily $X$ in a three-month period beginning 80 trading days and ending 21 trading days before a report date. The log increase in volatility in Figure 2 shown for day 0 is 1.308 , meaning volatility is $\exp (1.308)-1=270 \%$ higher on day 0 than during the baseline period.
} 


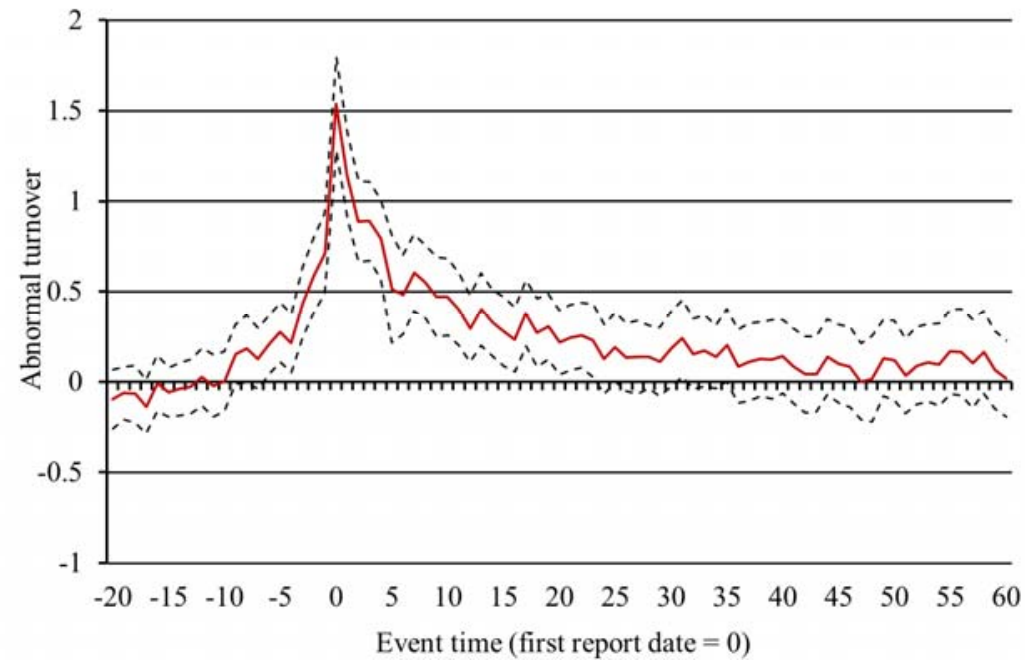

Figure 3. Average Abnormal Turnover

All this extra trading improves liquidity as measured by Amihud’s (2002) illiquidity measure. Figure 4 shows that liquidity spikes on the release day at $181 \%$ above the average firm’s baseline value (i.e., exp(abs(-1.033)) - 1) and remains significantly elevated for 28 trading days. (Interestingly, liquidity is unusually high in the month leading up to the report date. This coincides with the large pre-report price increases between trading day -20 and trading day -6 seen in Table 4, suggesting significant buyer interest in the target stocks ahead of the subsequent report release.)

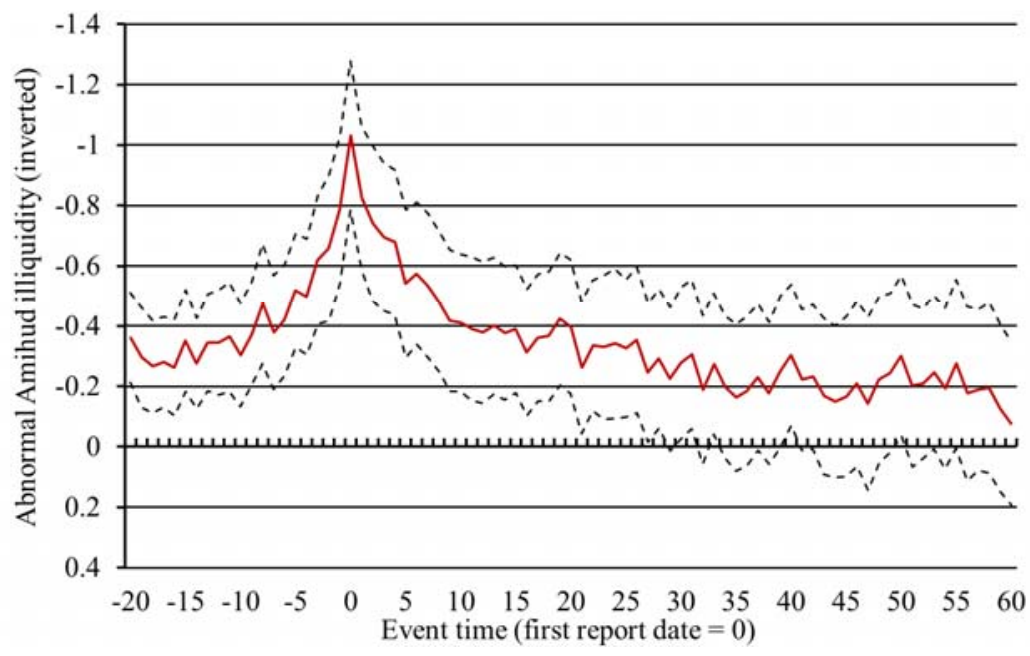

Figure 4. Average Abnormal Amihud Illiquidity Measure 


\subsection{Reaction in the Short Sale and Options Markets}

Who is responsible for the additional trading? Clearly, each trade involves a buyer and a seller, and only current shareholders (or "longs”) and short sellers can sell the stock. So the price pressure we see on the report day either comes from increased short selling or from increased selling by the longs. We first consider the short side of the market.

Figure 5 tracks the contribution of short sellers to the trading spike by plotting the average daily number of new shorts (scaled by shares outstanding) relative to the pre-event baseline. One day before the release, shorts briefly spike at $\exp (0.508)-1=66 \%$ above baseline $(p=0.002)$, perhaps as the arbs build or add to their short positions. The spike is, however, economically small: on average, only $0.48 \%$ of outstanding shares are newly shorted on day -1 . Given an average day -1 market capitalization of \$959.86 million, this means that new shorts amount to only around $\$ 4.61$ million in trading (i.e., $0.0048 * \$ 959.86 \mathrm{~m}$ ), not all of which will involve one of our sample arbs. These small numbers underscore the fact that the arbs in our sample do not have particularly deep pockets - and yet, as our results show, they have a large price impact and manage to correct misvaluations.

The spike in new shorts on day -1 is not only small but also short-lived. Beginning on the release day itself, new shorts are no more numerous than during the pre-release baseline month. Thus, new shorts do not appear to be responsible for the additional trading we saw in Figure 3. This is somewhat unexpected. Abreu and Brunnermeier (2002) argue that arbitrageurs face “synchronization risk”, meaning they do not know when other arbs will start targeting an overvalued firm. If a critical mass of arbs is required for a shorting strategy to be profitable, synchronization risk can lead to a coordination problem and so to insufficient arbitrage.

However, by publishing their information, arbs remove the synchronization risk; the publication is essentially a coordination device. And yet we see no increase in shorting activity. Why not? 


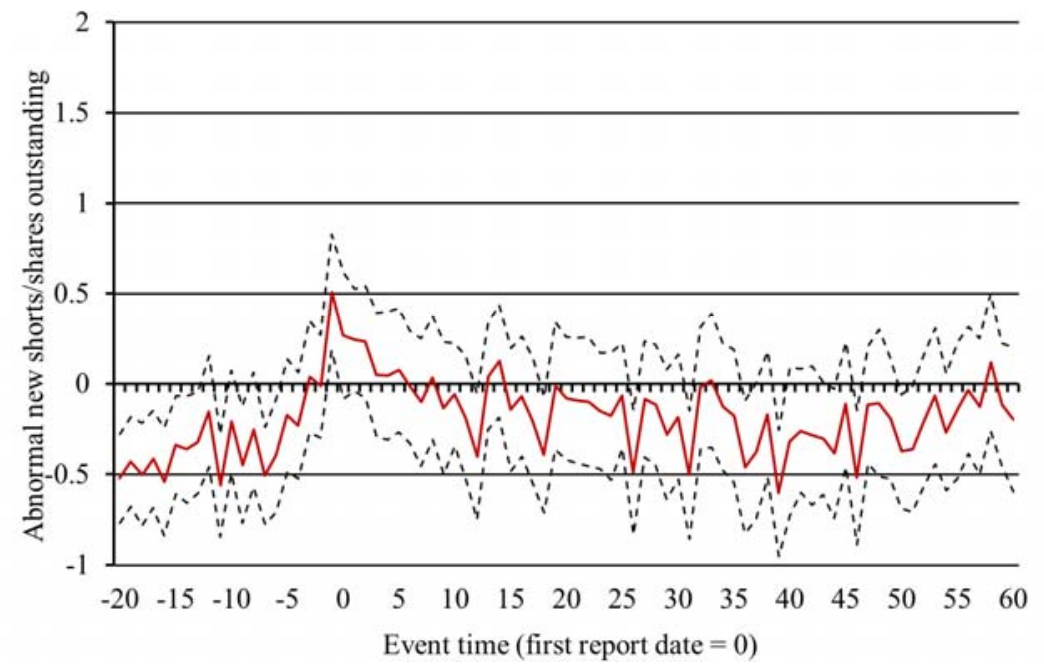

Figure 5. Average Abnormal Short Trades

The reason is simple. The lack of unusual activity in the shorting market, once a report has been released, reflects a drastic increase in the cost of shorting and a concomitant fall in the supply of lendable stock available for shorting. Figure 6a below shows that the cost of initiating new shorts rises significantly one day before a report is released (perhaps in response to the arbs building their short positions) and then jumps to 52\% above the baseline on average on the release day. It continues to drift higher, to a level $238 \%$ above the baseline by trading day 60 (i.e., $\exp (1.217)-1)$. As Figure $6 \mathrm{~b}$ shows, this puts the cost of initiating new shorts in the 81st percentile on the release day, drifting up to the 90th percentile over the next three months.

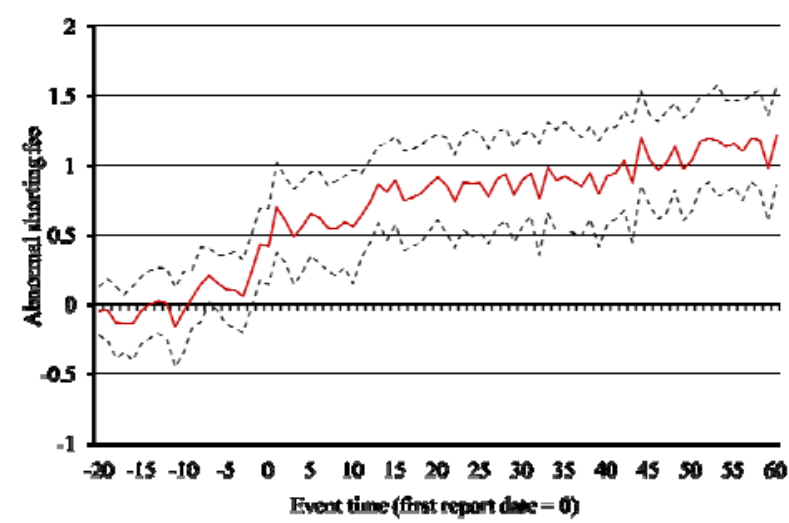

Figure 6a. Average Abnormal Shorting Fee

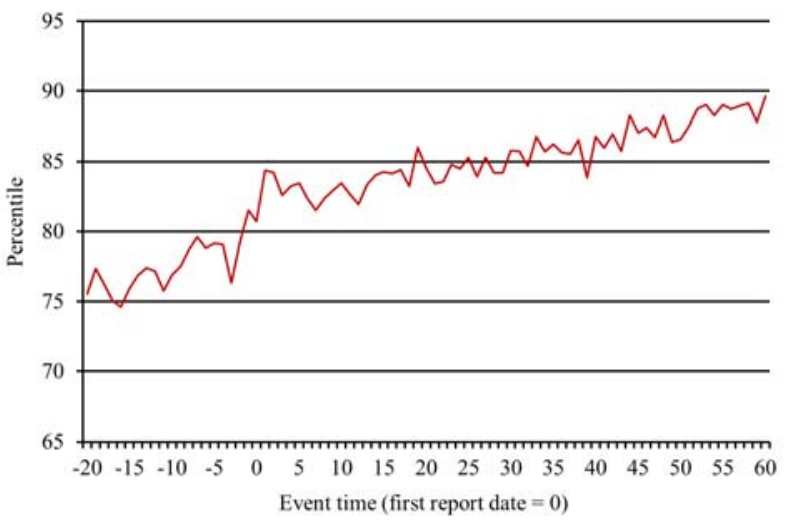

Figure 6b. Mean Percentile Rank

Part of the reason for the cost increase is presumably an increase in demand by short sellers, 
but part of it appears to be the result of a fall in the supply of lendable stock. Anecdotally, some targets put pressure on their shareholders to recall stock out on loan, to put a squeeze on short sellers. ${ }^{11}$ Figure 7 , though noisy, shows that the supply of lendable stock becomes unusually low, relative to the baseline, on the report date and remains at $20 \%$ to $30 \%$ below the baseline for the next three months. Notably this occurs even while lending fees are exceptionally high.

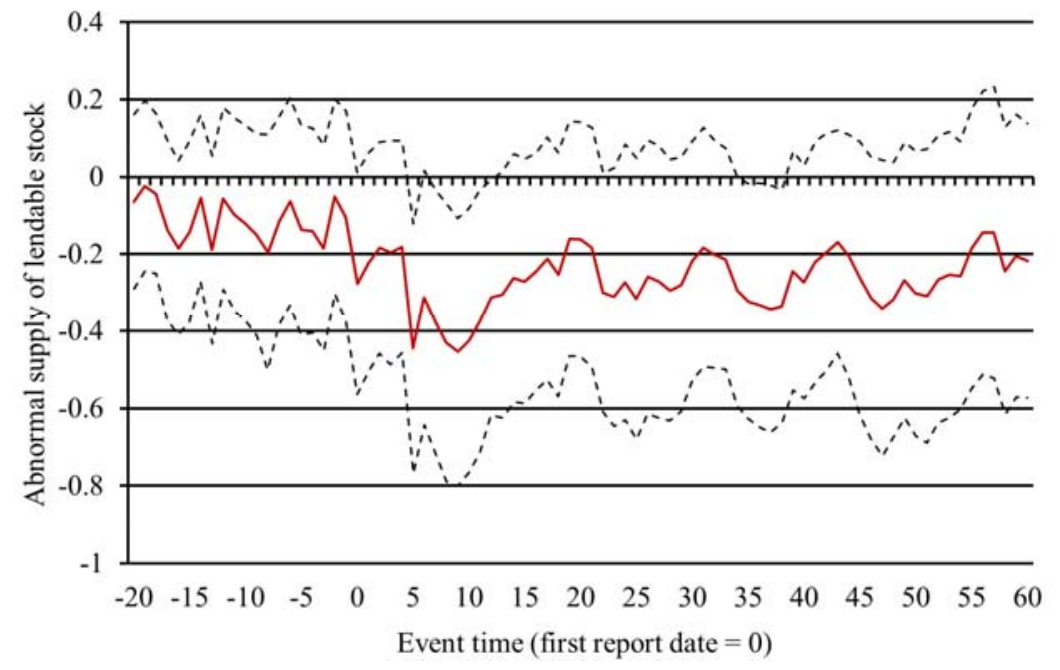

Figure 7. Average Abnormal Supply of Lendable Shares

In light of this tightening in the short sale market, market participants might try to trade on the information revealed in the arbs' reports via the option markets instead. However, this too appears to be difficult. Figure 8 shows an uptick in put option trading on the report date among the 69 targets with traded options, but the uptick is not statistically significant and anyway shortlived.

\footnotetext{
${ }^{11}$ For example, a target company issued the following press release in response to the release of a report: "The Company believes that short sellers' attempts to drive down the stock price and harm the Company's shareholders are likely to increase [...] In this context, the Company believes that an important way to protect shareholder value is to limit short sellers' ability to borrow stocks and shareholders can contribute by reviewing whether their custodians or brokers are lending their shares to third parties.” (PR Newswire, August 3, 2011)
} 


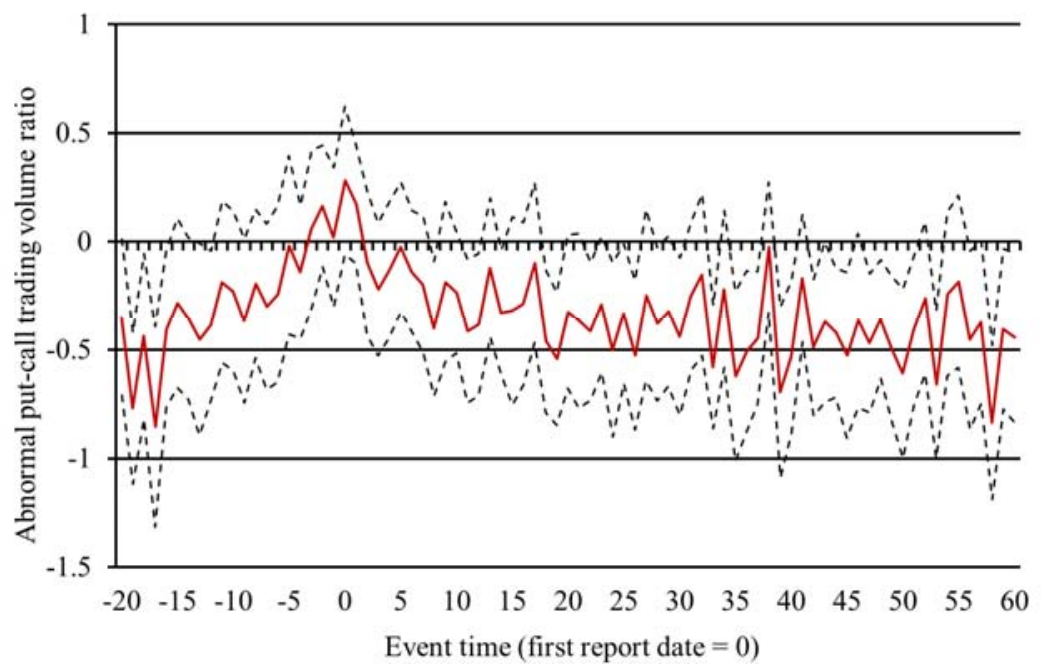

Figure 8. Average Abnormal Put Option Trading Volume

Figure 9a shows why the put trading volume does not increase significantly when a report is released: puts become unusually expensive. The implied volatility of put options (a measure of put prices) drifts up significantly in the three weeks before the report date (consistent with some arbs buying puts to profit from the negative information they are about to release) and spikes at $46 \%$ above baseline on the day a report is released (i.e., $\exp (0.377)-1)$. Part of this spike reflects the increase in volatility we saw in Figure 2 above, but whereas volatility quickly reverts to the baseline, implied put-option volatility remains significantly elevated, at around $25 \%$ above baseline, for the next three months. This suggests that puts are in unusually high demand. 


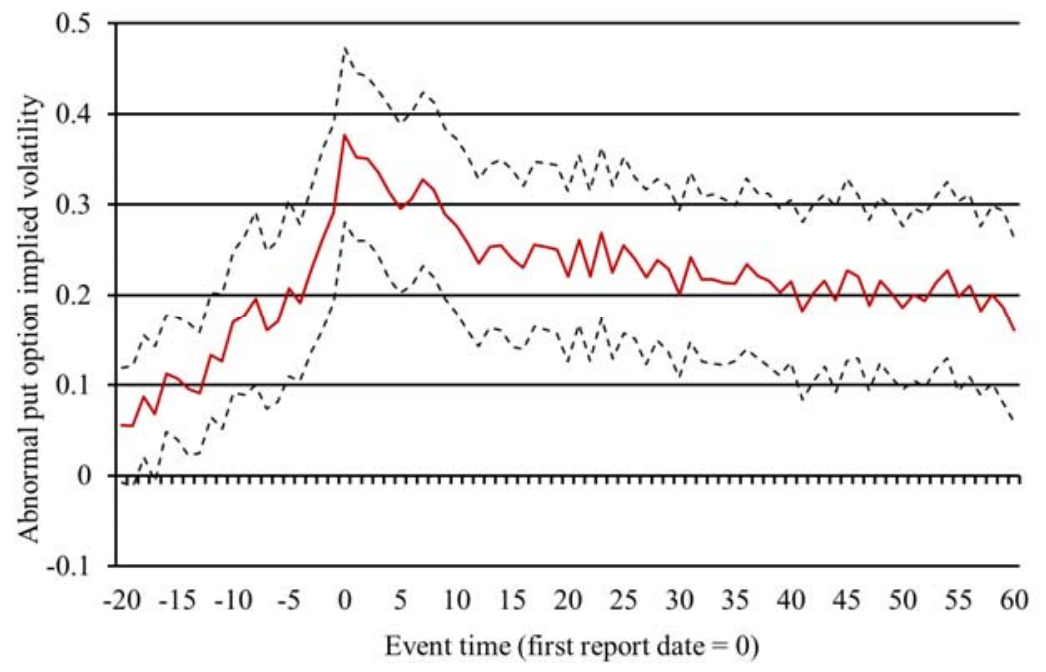

Figure 9a. Average Abnormal Cost of Put Options

Another way to see that puts become expensive - beyond what is reasonable given the (temporary) increase in volatility shown in Figure 2 - is to compare the implied volatilities of puts to the implied volatilities of calls with the same strike price and exercise date. (For all variable definitions and details of their construction, see Appendix A.) By put-call parity, the implied volatilities of puts and calls must be identical and so the ratio of put and call implied volatilities should be one - unless there are significant costs of carry, such as short sale constraints. Figure 9b shows that puts begin to depart from parity three days before the report date on average, with the ratio settling at $10 \%$ above the pre-event baseline once the report has been released and remaining there for the next three months. This is consistent with short sale constraints becoming even tighter, making puts unusually expensive. As Figure 9c shows, once the arbs release their reports, target companies' put prices move into the top quartile of the CRSP distribution. 


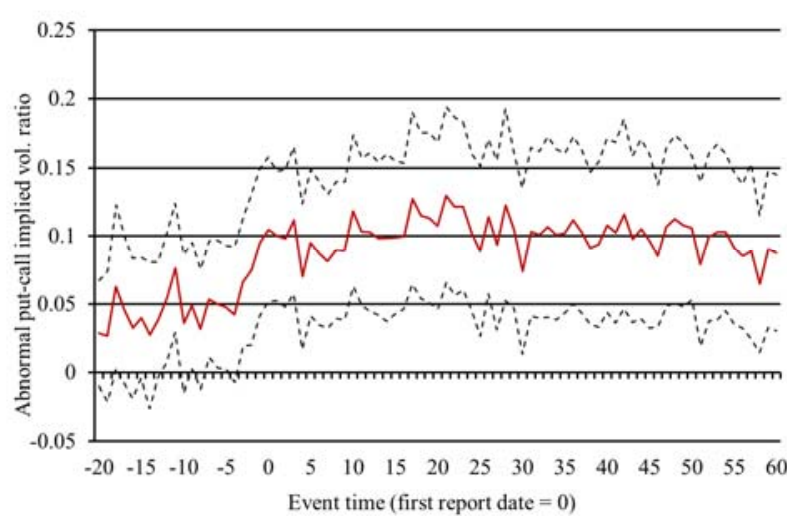

Figure 9b. Abnormal Cost of Puts Relative to Calls

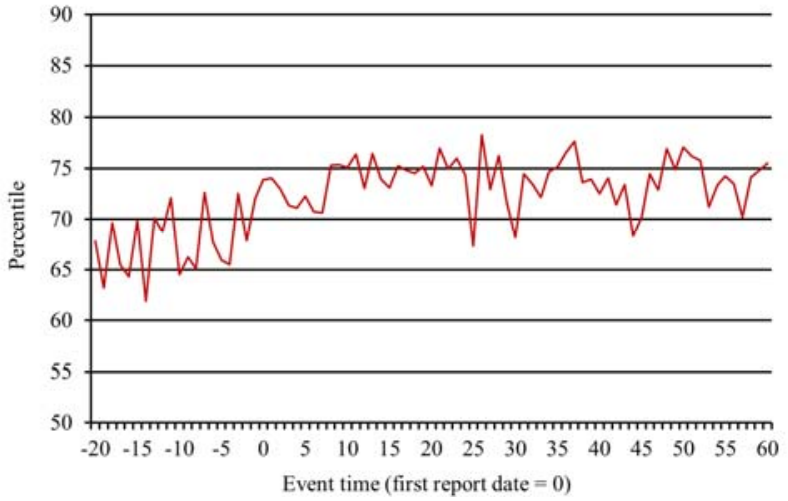

Figure 9c. Mean Percentile Rank

In summary, the companies targeted by the arbs in our sample are simply too hard to arbitrage directly - through shorting or put options - for publication of the reports to act as a coordination device in the sense of Abreu and Brunnermeier (2002). ${ }^{12}$ Another mechanism is therefore needed.

\subsection{Reaction by Long Investors and Price Correction}

The patterns in Figures 5 to 9 show that neither new shorts nor trading in the options market are likely to be the main cause of the report-day price falls shown in Table 2. As we have noted, this is not surprising, given that the targets have many of the characteristics traditionally associated with short sale constraints and limits to arbitrage. What then explains the price falls? The answer is trading by the one group of investors who are unconstrained: investors with long positions in the target companies' shares. Figure 10 illustrates that the spike in overall trading volume we saw in Figure 3 is driven by a massive increase in trading by the longs. On the report day, long trading is $415 \%$ above the baseline $(=\exp (1.639)-1)$ and stays significantly elevated for the next month.

\footnotetext{
${ }^{12}$ But see Zuckerman (2011) for evidence of synchronized arbitrage involving public announcements in a setting where limits to arbitrage are much less likely to be binding.
} 


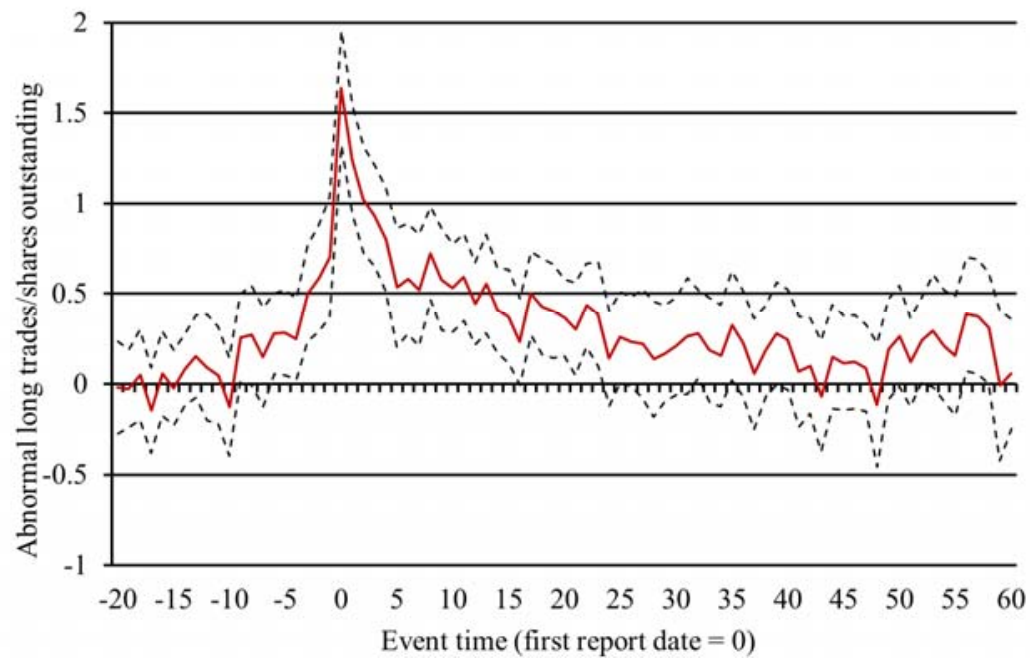

Figure 10. Average Abnormal Long Trades

While data limitations prevent us from signing the direction of the long investors' trades, the share price falls on the report day seen in Table 2 make it highly likely that longs are net sellers (the alternative being that they sell to each other). Figure 11 shows what happens to target companies' share prices as the longs sell: not only do prices fall, by $8.18 \%$ on the report day, they continue to drift lower over the next three months to end down $21.9 \%$ net of market movements. At no time over this window do prices recover.

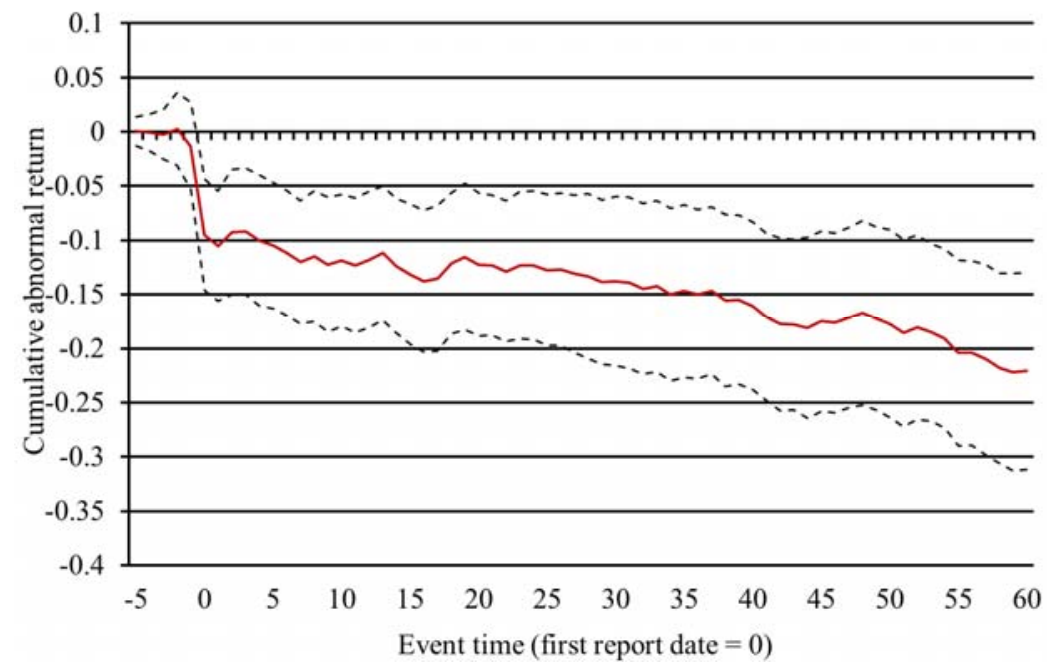

Figure 11. Cumulative Abnormal Returns Around Report Releases

Though not shown in the figure, the mean cumulative abnormal return is $-56.8 \%$ over the 12 
months following the release of a report, with 80 of the 113 targets experiencing negative abnormal returns. This suggests that the information the arbs release usually proves correct.

\subsection{How Accurate Are the Reports?}

The reports not only make an impression on investors; they also influence the SEC, the stock exchanges - and of course trial lawyers. Using SEC filings and Factiva searches, we find that through the end of 2012, 53\% of targeted companies are involved in class action lawsuits, 35\% are delisted by an exchange (usually out of public-interest concerns), and $25 \%$ are formally investigated by the SEC or the Department of Justice (occasionally for fraud). ${ }^{13}$ In fact, only $19 \%$ of the 285 reports that raise material concerns (rather than simply claiming a company is overvalued based on a reinterpretation of known data) are subsequently disproved by independent parties such as the SEC, the DoJ, or an exchange.

Moreover, subsequent actions taken by the target companies indirectly confirm that the arbs' information is usually accurate. Through the end of 2012, $80 \%$ of targets change management, $38 \%$ replace the auditor or see their auditor resign, and 23\% restate their earnings.

\subsection{Do Arbs Make Money on Their Information Production?}

While we do not know the costs involved in producing the information contained in the reports, our data allow us to estimate the arbs' trading profits. Assuming that they take a short position five days before the report day (which looks consistent with the patterns found in Figures 5 and 6a) and then follow a marked-to-market borrow-and-hold strategy, their cumulative abnormal profit equals the negative of the cumulative abnormal return shown in Figure 11 above minus the cumulative shorting fee.

Figure 12 shows that this borrow-and-hold strategy turns profitable as soon as the report is released, making an average return of $8.13 \%$ on the report day and a cumulative abnormal profit

\footnotetext{
${ }^{13}$ Between them, the SEC and the DoJ launch fraud investigations in 14 cases and bring fraud charges in 9 cases, targeting about the same number of U.S. and Chinese companies.
} 
of $18.2 \%$ over the first three months. These profit estimates are conservative to the extent that they ignore the potential for additional - and leveraged - returns through the use of put options. They also ignore that arbs, knowing that their reports will cause short-term spikes in volatility, could potentially set up profitable trading strategies in the options market (such as zero-beta straddles or butterflies) designed to capitalize on the volatility spikes.

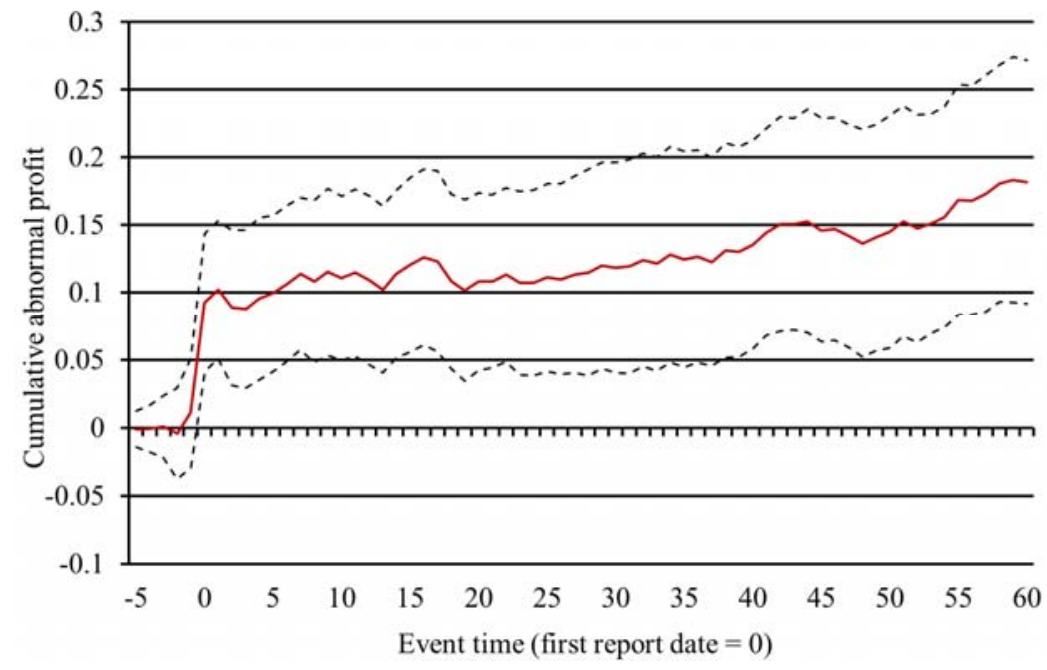

Figure 12. Average Cumulative Abnormal Profit Around Report Releases

Are these trading profits likely to cover the arbs' information production costs? An $18.2 \%$ risk-adjusted return net of shorting fees implies dollar gains of \$182,000 on an initial short position of $\$ 1 \mathrm{~m}, \$ 364,000$ on an initial short position of $\$ 2 \mathrm{~m}, \$ 546,000$ on an initial short position of \$3m, and so on - plus whatever profits the arbs can make through option trading strategies. While we cannot know for sure, these numbers seem sufficient to cover analyst salaries, private investigators, and so on.

\section{Pinpointing the Mechanism}

The results so far suggest that the arbs do not have deep enough pockets to correct the mispricing on their own, given the short-sale constraints surrounding their targets. Our conjecture is that the arbs attempt to circumvent these constraints by making their information public in an effort to persuade the longs to sell. This would be consistent with the observed 
massive increase in trading by the longs. If successful, this strategy will not only result in a price correction that translates into gains on the arbs' short positions; it will also reduce noise trader risk by making it less likely that prices diverge even further from fundamentals in the short-run and thereby put a squeeze on the arbs’ short positions.

For this strategy to work, the reports have to contain credible information. In Section 4.1, we show that more credible reports result in more rapid price corrections and larger profits to the arbs. Section 4.2 adds nuance to this result by showing that reports that go beyond claiming a stock is overvalued (by providing new information that is costly to acquire) elicit larger and speedier market reactions. Section 4.3, finally, shows that arbs make money even in the hardestto-short cases in our sample.

\subsection{Credibility}

Reports should only induce longs to sell if the information they contain is credible. The arbs clearly understand this: many prominently post their past performance on their websites. For example, Citron Research maintains a list of its targets that have subsequently been targeted by regulators - more than 50 as of January 2014 (see http://en.wikipedia.org/wiki/Andrew_Left).

Rather than relying on these posts, we construct our own measure of credibility. Specifically, to determine whether a report is likely to be credible, we examine each arb’s prior track record, on the assumption that arbs with a stronger track record are more readily believed when they target a stock. We measure an arb’s track record at time $t$ as the rolling mean of the three-month cumulative abnormal returns of all his previous reports (issued at least three months before time $t$, to avoid look-ahead bias) that are independently confirmed by a third party (such as the SEC, the DoJ, or an exchange). ${ }^{14}$ Using all 332 reports in our sample, we then code a report issued at time $t$ as more credible if the arb’s prior track record produced profits (a negative rolling mean

\footnotetext{
${ }^{14}$ We require each arb to have issued at least two reports before we compute a track record. Results are not sensitive to the choice of a three-month window.
} 
CAR), and as less credible otherwise. This yields 167 reports coded as more credible and 36 reports coded as less credible. ${ }^{15}$ Note that an arb’s track record evolves over time such that he can gain or lose credibility depending on how accurate his reports prove to be. The final column of Table 1 reports what fraction of each of the 17 arbs' reports is coded as more credible.

Table 5, Panel A splits the sample by this measure of credibility. When a more credible arb is the first to issue a report on a target, the target's share price falls by an average of $12.5 \%$ on the report day, net of market movements $(p<0.001)$. This is a significantly larger than the $-4.5 \%$ average price fall for less credible reports, which in turn is not significantly different from zero $(p=0.15)$. If we include follow-on reports by this or other arbs, the pattern is similar: more credible reports are greeted with a significant price fall averaging $5.8 \%$ on the release day $(p<0.001)$, compared to a price fall of only $2.1 \%$ for less credible reports $(p=0.091)$.

Turnover tells a similar story. Both overall turnover and trading involving longs respond significantly more strongly, on the report day, to more credible reports. As Figure 13 below shows, the difference is stark and persists for many days.
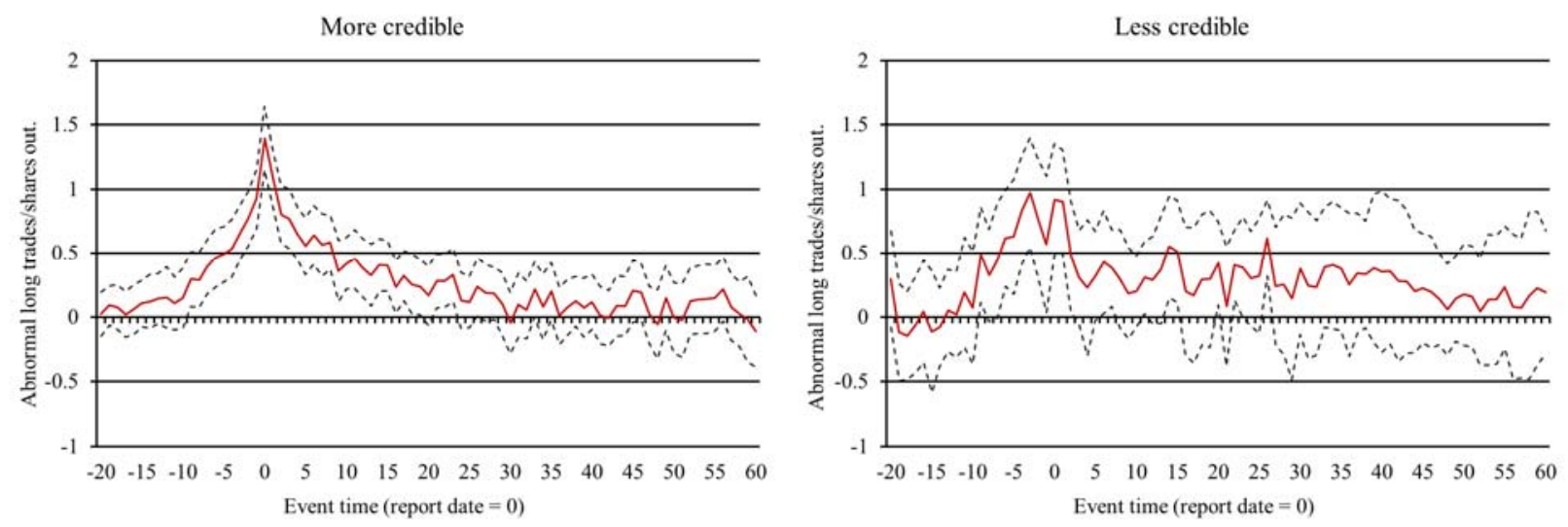

Figure 13. Abnormal Long Trades Sorted by Credibility

Consistent with these turnover patterns, prices converge faster in response to more credible

\footnotetext{
${ }^{15}$ We lose 129 of the 332 reports, in part because we require at least two reports to compute a track record; in part because we require that prior reports are at least 60 trading days old before we can classify the current report as more or less credible; and in part because reports that allege overvaluation based merely on a reinterpretation of already known data are excluded.
} 
reports. As a result, a borrow-and-hold strategy initiated five days before the release day of a more credible report becomes immediately profitable upon release and generates abnormal profits, net of shorting fees, averaging $16.2 \%$ by day +60 . The rapid speed with which the price correction occurs implies a much reduced noise trader risk. Less credible reports, in contrast, do not move prices significantly, either on the release day or with any kind of lag. By day +60 , for example, cumulative abnormal profits average a more modest and statistically insignificant $11.4 \%$ net of shorting fees $(p=0.130)$.
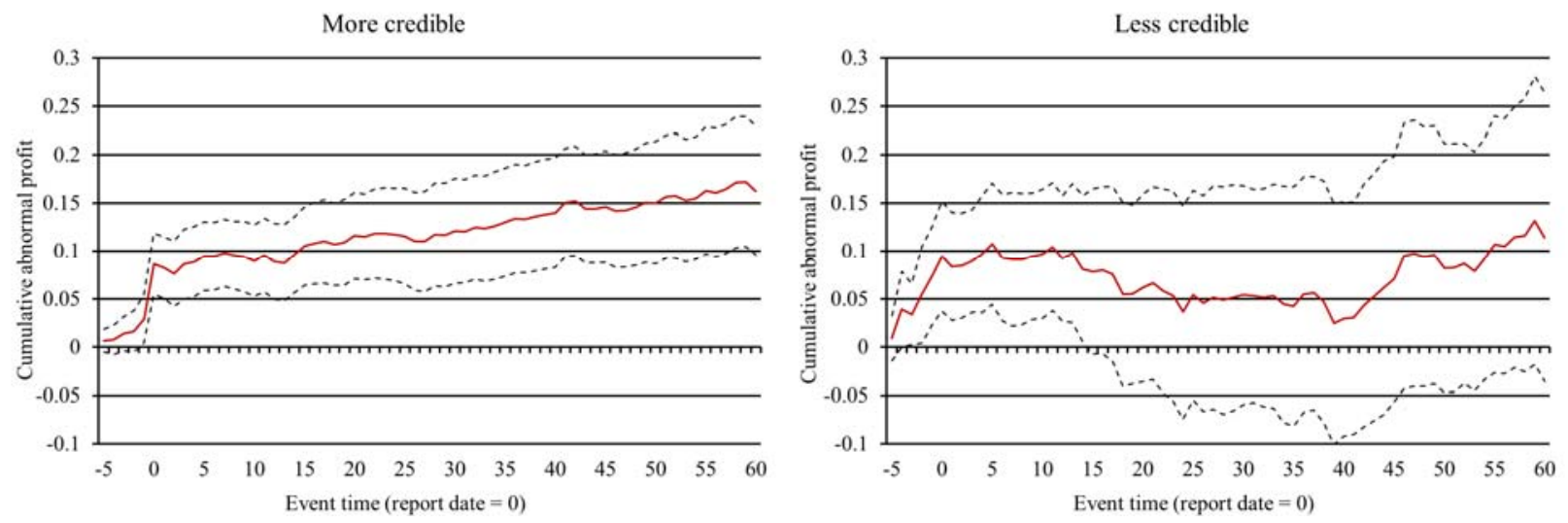

Figure 14. Cumulative Abnormal Profits Sorted by Credibility

\subsection{Nature of Information Discovery}

Credibility appears to be necessary but is probably not sufficient to ensure the longs will listen. What likely also matters is what the arb has to say. Table 5, Panel B splits the sample of first reports into those that convey the results of information production (i.e., the discovery of facts previously unknown to investors) and those that result from information processing (i.e., the reinterpretation of already known data). The report-day returns average $-10.2 \%$ when a report reveals new information $(p<0.001)$, compared to a statistically insignificant $-1.7 \%$ when the report merely claims a stock is overvalued based on a different interpretation of known data $(p=0.375)$. In other words, investors largely ignore claims of overvaluation if not backed up by new facts and hard evidence. The difference between the two cases is highly statistically 
significant $(p=0.001)$.

Turnover tells a similar story: both the overall increase in turnover and the reaction by longs is significantly stronger for reports that go beyond claiming a stock is overvalued by providing new information that is costly to acquire. In fact, as Figure 15 shows, mere claims of overvaluation do not appear to influence long trading much at any horizon.
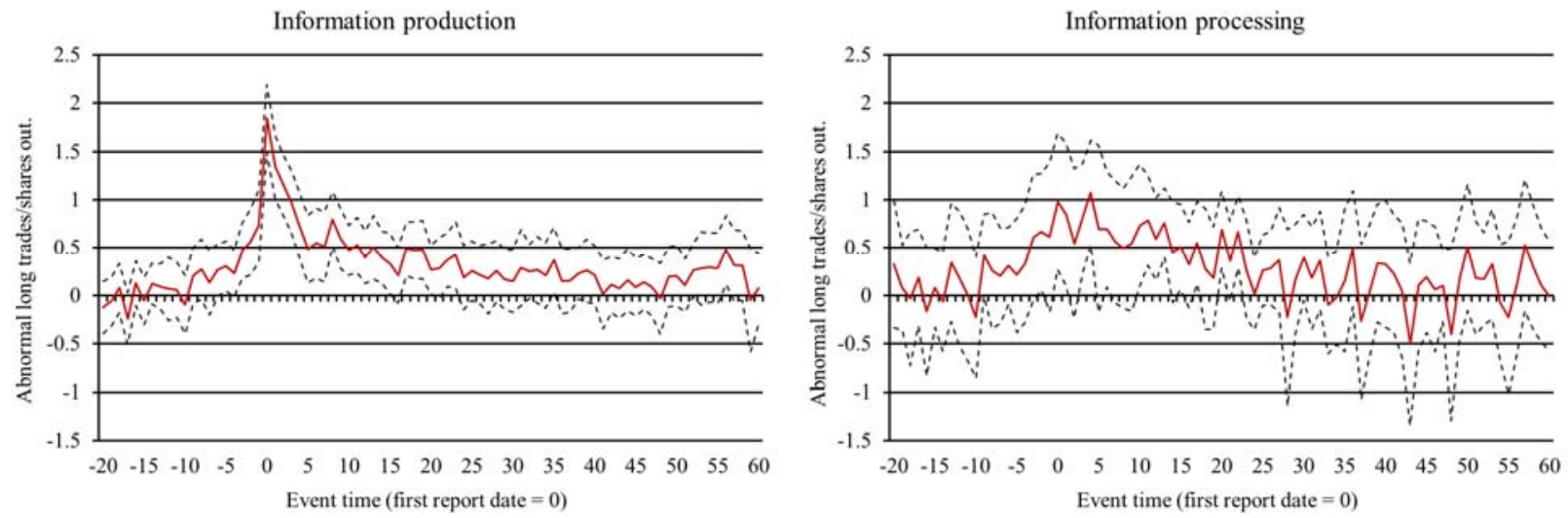

Figure 15. Abnormal Long Trades Sorted by Type of Report

These patterns imply that arbs who produce new information should make higher profits than arbs who merely process existing information to arrive at their opinion. Figure 16 bears this prediction out. It shows average cumulative abnormal profits for a marked-to-market borrowand-hold strategy that shorts a target company’s stock five days before the first report is released and holds the stock for three months, net of shorting fees. Evidence-based reports that convey the results of information production generate significant profits as soon as they are released, peaking at $22.7 \%$ by day +60 on average. Opinion-based reports that merely claim a stock is overvalued, on the other hand, have a harder time convincing investors of their case and end up never making significant profits (not even after three months). 

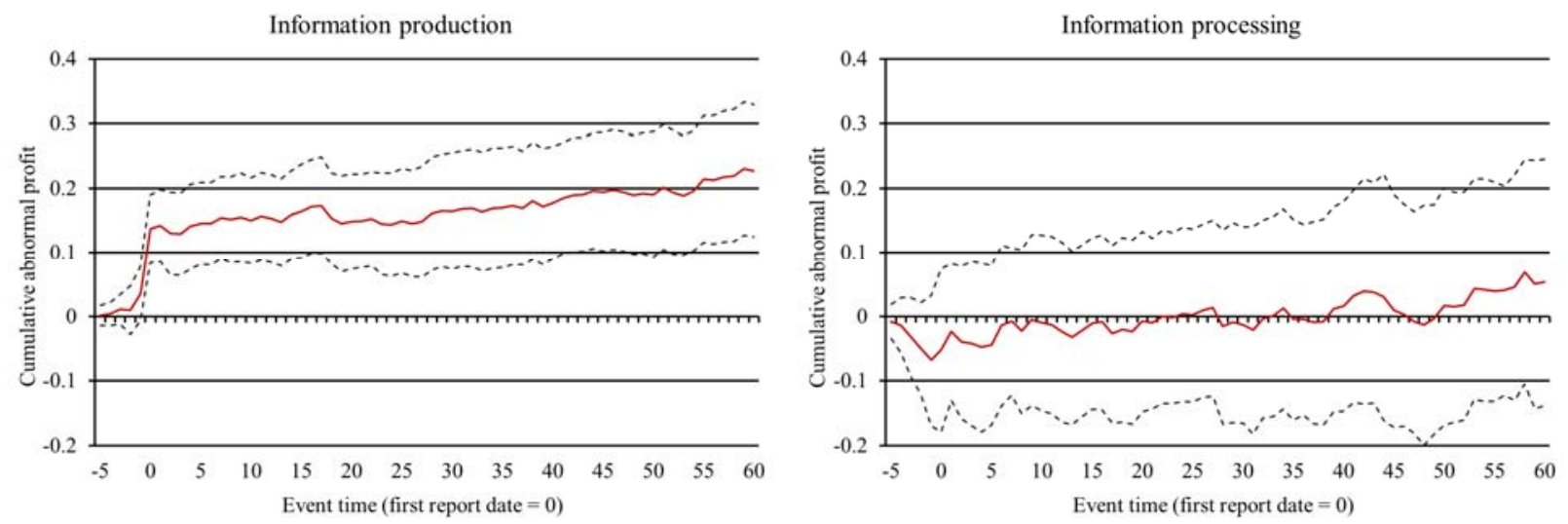

Figure 16. Cumulative Abnormal Profits Sorted by Type of Report

\subsection{Shorting Costs}

Our results suggest that arbs who credibly reveal novel information are able to persuade long shareholders to sell and thereby contribute to a price correction which in turn generates an economically meaningful return for the arbs on their information production. We next show that this is true in even the most constrained, hardest to short stocks in our sample.

We use two measures to capture shorting cost: the level of the shorting fee and the supply of lendable stock available for borrowing. For the first measure, we sort target stocks by the average daily shorting fee during the trading month ending one month before the first report and split the sample at the median. Figure 17a shows that the arbs make significant three-month abnormal profits in high-shorting-fee stocks, even net of shorting fees. The cumulative abnormal profits average $18.6 \%$ ( $p=0.006$ ), very similar to the average profit of $19.2 \%$ on low-shorting-fee stocks ( $p=0.006)$. In other words, gross returns (i.e., returns due to price corrections) are sufficiently greater in high-shorting-fee stocks to make up for the higher shorting fees, such that net returns end up being very similar - despite the difference in the cost of building the initial short position. This implies that when shorting fees are high, the arbs predominantly target companies that are more glaringly mispriced in the light of the information produced. 

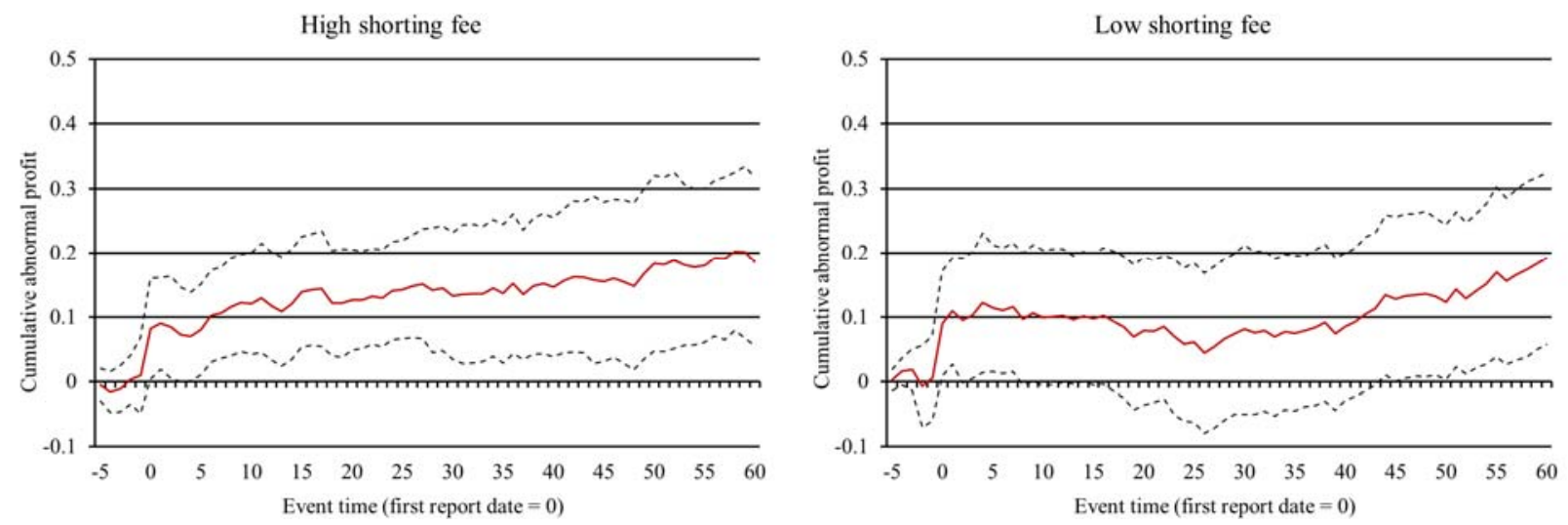

Figure 17a. Cumulative Abnormal Profits Sorted by Shorting Fee

We obtain qualitatively similar results with our second measure of shorting cost. When we sort on the supply of lendable stock available for borrowing, again splitting the sample at the median, we find that the arbs make money, net of shorting fees, regardless of the level of shorting costs. If anything, they make greater returns in the harder-to-borrow stocks, averaging 24.2\% ( $p=0.002)$ after 60 days, than in easier-to-borrow stocks, averaging $14.4 \%(p=0.019)$, though the difference is not statistically significant $(p=0.296)$.
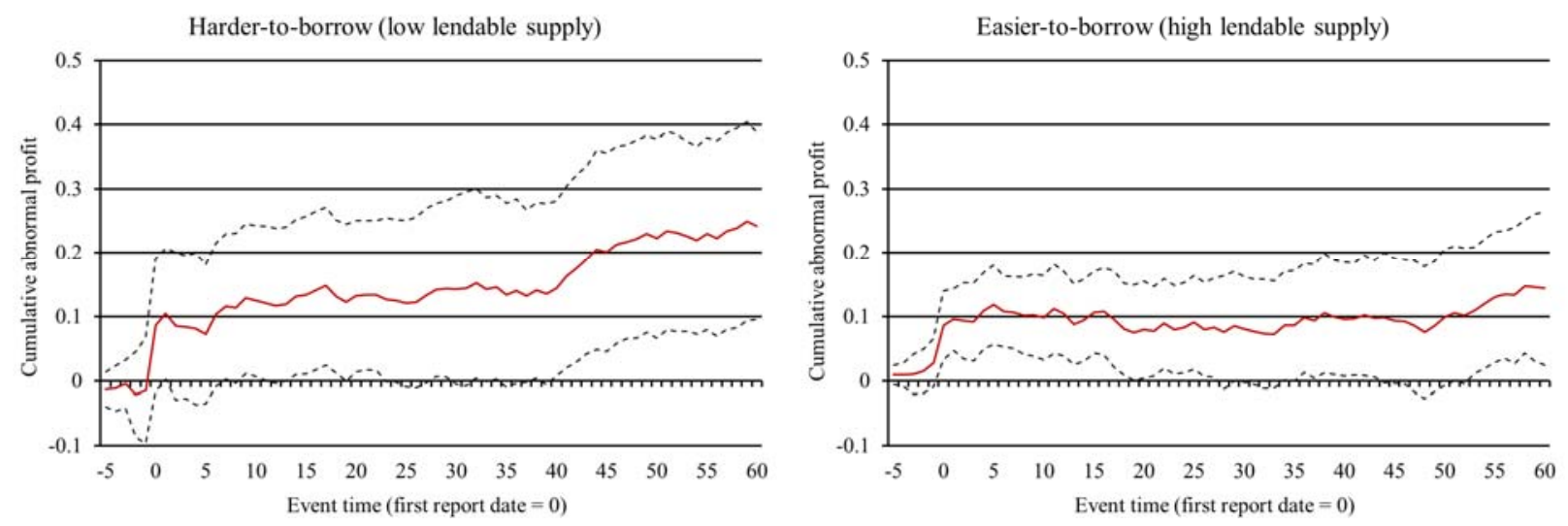

Figure 17b. Cumulative Abnormal Profits Sorted by Supply of Lendable Stock

Table 5, Panels C and D show that the high- and low-shorting-cost subsamples experience similar spikes in turnover and in long trading when a report is released to the public, whether we sort on shorting fees or the supply of lendable stock. This is consistent with our proposed mechanism: if, as we propose, the price correction emanates not from the shorting market (whose 
features Panels C and D sort on) but from long shareholders' responses to the negative information revealed in the reports, it should make no difference how severe a set of short-sale constraints a target company happens to have.

\section{Conclusions}

We report evidence of (risky) arbitrage correcting mispricing (and doing so profitably) in a setting characterized by costly information discovery, arbs with shallow pockets, severe short sale constraints, and a high risk of mispricing persisting - that is, a setting theory suggests should suffer from severe limits to arbitrage.

The financial innovation that allows the arbs to circumvent these limits to arbitrage relies on credibly revealing their information to the market, in an effort to induce the unconstrained investors - i.e., the longs - to sell. This not only helps overcome short-sale constraints but also accelerates the price correction and thereby reduces the risk of noise traders moving prices even further from fundamentals in the short-run, which might otherwise force the arbs to liquidate their short positions at a loss. Credibility is key: arbs who lack (or lose) a track record of producing reliable new evidence are ignored by investors and so do not move prices. Producing new evidence also is key: arbs who simply express the opinion that a stock is overvalued, based purely on existing data, are similarly ignored by investors.

In principle, revealing the information creates the potential for coordinated action by multiple arbitrageurs to overcome the synchronization problem that Abreu and Brunnermeier (2012) talk about. But our results show that not even that is enough, on its own, to correct mispricing in our setting. The reason is that the short-sale constraints are quite severe for our target stocks, limiting the scope for coordinated action. And yet these limits to arbitrage can still be sidestepped, as long as the information is sufficiently credible to convince the longs to sell.

In conclusion, our results suggest that limits to (risky) arbitrage need not be as constraining 
as previously assumed: they can be sidestepped by the novel arbitrage mechanism we identify in this paper. This mechanism appears to have become increasingly popular. While we know of only three arbs who practiced it up to 2008, the mechanism was adopted by four new arbs in each of 2009 and 2010 and by six in 2011.

Our evidence also illustrates why financial markets need short sellers to function well. While some short sellers may indeed be speculators who do little more than destabilize share prices, as is often alleged, the short sellers in our sample are information producers who help correct mispricing and thereby help make markets more efficient. This is all the more remarkable given that many targets in our sample were held by highly sophisticated investors who apparently did not spot the overvaluation until it was too late. ${ }^{16}$

\footnotetext{
${ }^{16}$ According to media reports, investors that lost substantial amounts when arbs revealed their information include Paulson \& Co. (with a \$468m loss on Sino-Forest) and C.V. Starr \& Co. (with a \$6.5m loss on ChinaMedia Express). Other prominent investors who have suffered from the price fall upon the information release include Blackrock, Vanguard, Hartford Investment Management, Apollo Global Management, and Henderson Global Investors.
} 


\section{References}

Abreu, Dilip, and Markus Brunnermeier, 2002, Synchronization risk and delayed arbitrage, Journal of Financial Economics 66, 341-360.

Amihud, Yakov, 2002, Illiquidity and stock returns: Cross-section and time series effects, Journal of Financial Markets 5, 31-56.

Avramov, Doron, Tarun Chordia, and Amit Goyal, 2006, The impact of trades on daily volatility, Review of Financial Studies 19, 1241-1277.

Barberis, Nicholas, and Richard H. Thaler, 2003, A survey of behavioral finance, in: G.M. Constantinides, M. Harris, and R. Stulz (eds.), Handbook of the Economics of Finance, Elsevier Science.

Boehmer, Ekkehart, Charles Jones, and Xiaoyan Zhang, 2008, Which shorts are informed?, Journal of Finance 63, 491-527.

Brav, Alon, J.B. Heaton, and Alexander Rosenberg, 2004, The rational-behavioral debate in financial economics, Journal of Economic Methodology 11, 393-409.

Christophe, Stephen E., Michael G. Ferri, and James J. Angel, 2004, Short-selling prior to earnings announcement, Journal of Finance 59, 1845-1875.

Christophe, Stephen E., Michael G. Ferri, and Jim Hsieh, 2010, Informed trading before analyst downgrades: Evidence from short sellers, Journal of Financial Economics 95, 85-106.

Cohen, Lauren, Karl B. Diether, and Christopher J. Malloy, 2007, Supply and demand shifts in the shorting market, Journal of Finance 62, 2061-2096.

D’Avolio, Gene, 2002, The market for borrowing stock, Journal of Financial Economics 66, 271-306.

Dechow, Patricia M., Amy P. Hutton, Lisa Meulbroek, and Richard G. Sloan, 2001, Short sellers, fundamental analysis and stock returns, Journal of Financial Economics 61, 77-106.

DeLong, Bradford J., Andrei Shleifer, Lawrence Summers, and Robert J. Waldmann, 1990, Noise trader risk in financial markets, Journal of Political Economy 98, 703-738.

Desai, Hemang, K. Ramesh, S. Ramu Thiagarajan, and Bala V. Balachandran, 2002, An investigation of the information role of short interest in the NASDAQ market, Journal of Finance 52, 2263-2287.

Desai, Hemang, Srinivasan Krishnamurthy, and Kumar Venkataraman, 2006, Do short sellers target firms with poor earnings quality? Evidence from earnings restatements, Review of Accounting Studies 11, 71-90.

Diether, Karl B., Kuan-Hui Lee, and Ingrid Werner, 2007, Short-sale strategies and return predictability, Review of Financial Studies 22, 575-607.

Engelberg, Joseph, Adam V. Reed, and Matthew Ringgenberg, 2012, How are shorts informed? Short sellers, news, and information processing, Journal of Financial Economics 105, 260278.

Figlewski, Stephen, 1981, The informational effects of restrictions on short sales: Some empirical evidence, Journal of Financial and Quantitative Analysis 16, 463-476. 
Friedman, Milton, 1953, The case for flexible exchange rates, in: Essays in Positive Economics, University of Chicago Press.

Gromb, Denis, and Dimitri Vayanos, 2002, Equilibrium and welfare in markets with financially constrained arbitrageurs, Journal of Financial Economics 66, 361-407.

Harrison, Michael J., and David M. Kreps,1978, Speculative investor behavior in a stock market with heterogeneous expectations, Quarterly Journal of Economics 92, 323-336.

Hirshleifer, David, Siew Hong Teoh, and Jeff Jiewei Yu, 2011, Short arbitrage, return asymmetry, and the accrual anomaly, Review of Financial Studies 24, 2429-2461.

Jain, Archana, Pankaj K. Jain, Thomas H. McInish, and Michael McKenzie, 2013, Worldwide reach of short selling regulations, Journal of Financial Economics 109, 177-197.

Jones, Charles, and Owen A. Lamont, 2002, Short sales constraints and stock returns, Journal of Financial Economics 66, 207-239.

Karpoff, Jonathan M., and Xiaoxia Lou, 2010, Short sellers and financial misconduct, Journal of Finance 65, 1879-1913.

Lamont, Owen A., 2012, Go down fighting: Short sellers vs. firms, Review of Asset Pricing Studies 2, 1-30.

Lamont, Owen A., and Richard H. Thaler, 2003, Can the market add and subtract? Mispricing in tech stock carve-outs, Journal of Political Economy 111, 227-268.

Lee, Charles M.C., Kevin K. Li, and Ran Zhang, 2013, Shell games: Are Chinese reverse merger firms inherently toxic?, Working paper, Stanford University.

Loh, Roger K., and Rene M. Stulz, 2011, When are analyst recommendation changes influential?, Review of Financial Studies 24, 593-627.

Nagel, Stefan, 2005, Short sales, institutional investors and the cross section of stock returns, Journal of Financial Economics 78, 277-309.

Saffi, Pedro A.C., and Kari Sigurdsson, 2011, Price efficiency and short selling, Review of Financial Studies 24, 821-852.

Shleifer, Andrei, and Robert Vishny, 1997, The limits of arbitrage, Journal of Finance 52, 35-55.

Womack, Kent L., 1996, Do brokerage analysts’ recommendations have investment value?, Journal of Finance 51, 137-167.

Zuckerman, Roy, 2011, Synchronized arbitrage and the value of public announcements, Working Paper, Rutgers University. 


\section{Appendix A. Variable Definitions.}

\section{Outcome variables}

$\underline{\text { Returns and profits: }}$

$\boldsymbol{C A R}$ is the cumulative abnormal return over a specified event window. It is constructed using the Fama-FrenchCarhart benchmark. Factor loadings are estimated in a one-year pre-event window ending 61 trading days before the report date, and cumulative abnormal returns during the specific event window are calculated using this estimated model as a benchmark.

Cumulative abnormal profit measures the return to a borrow-and-hold strategy that goes short the stock on day $t$, marks the position to market on a daily basis, and closes out the position on day $T$. It is measured as the negative of the cumulative abnormal return (CAR) net of the cumulative daily shorting fee.

Daily trading and shorting variables:

Turnover is defined as the total number of shares traded (CRSP variable vol) in a day divided by the number of shares outstanding (CRSP variable shrout).

New shorts/shares outstanding is the number of new shorts initiated (as proxied by the number of new shares on loan) on a given day divided by the number of shares outstanding (CRSP variable shrout). The number of daily new shares on loan is obtained from DataExplorers (now owned by Markit), a securities lending data provider.

Long trades/shares outstanding is equal to the difference between turnover and new shorts/shares outstanding (as defined above). In other words, it is the number of traded shares on a given day that are not attributable to short sellers, divided by the total number of shares outstanding (CRSP variable shrout).

Shorting fee is the daily cost of initiating new short positions (i.e., the daily cost of borrowing new shares from equity lenders). Data are obtained from DataExplorers (now owned by Markit), a securities lending data provider.

Supply of lendable stock is defined as the number of shares available for borrowing on a given day divided by the number of shares outstanding (CRSP variable shrout). Data on shares available for borrowing are from DataExplorers (now owned by Markit), a securities lending data provider.

Daily variables constructed using intra-day data from TAQ:

Volatility is defined as the square root of the sum of the squared continuously compounded returns over the day. Following Avramov, Chordia, and Goyal (2006), we compute the continuously compounded returns using TAQ prices sampled every five minutes. When stocks do not trade at exactly five-minute intervals, we use the trade price closest to the five-minute mark. Results using quote prices are very similar. The variable is winsorized at the $1 \%$ and $99 \%$ to reduce the impact of outliers.

Amihud's (2002) illiquidity measure is defined as the average, over a day, of the absolute value of the five-minute continuously compounded return multiplied by 1,000,000 which then is divided by the dollar trading volume within the same five-minute interval. We compute the continuously compounded returns using TAQ prices sampled every five minutes. Results using quote prices are very similar. The variable is winsorized at the $1 \%$ and $99 \%$ to reduce the impact of outliers.

\section{Daily options-related variables (from OptionMetrics):}

Put-call trading volume ratio is constructed as follows. First, for each pair of traded put and call options with the same strike price (OptionMetrics variable strike_price) and exercise date (OptionMetrics variable exdate), we compute the put-call ratio of the daily trading volume (OptionMetrics variable volume). Second, we compute the weighted average of the daily trading volume ratios for all the put and call option pairs, weighted by open interest (OptionMetrics variable open_interest) on the corresponding put-call option pair for a given stock. 
Put option implied volatility is the weighted average of the implied volatility of all traded put options on a day for a given stock, weighted by open interest (OptionMetrics variable open_interest) on each of the traded put options for that stock. The implied volatility measure for each traded put option is obtained directly from OptionMetrics (variable impl_volatility).

Put-call implied volatility ratio is constructed as follows. First, for each pair of traded put and call options with the same strike price (OptionMetrics variable strike_price) and exercise date (OptionMetrics variable exdate), we compute the put-call ratio of the daily implied volatilities (OptionMetrics variable impl_volatility). Second, we compute the weighted average of the daily implied volatility ratios for all the put and call option pairs, weighted by open interest (OptionMetrics variable open_interest) on the corresponding put-call option pair for a given stock.

Firm characteristics (measured as of the most recent calendar month-end before a first report):

Market capitalization is defined as the product, reported in millions, of the end-of-month share price (CRSP variable prc) and the total number of shares outstanding (CRSP variable shrout).

Book/market ratio is measured as the ratio of a firm's book value of equity (Compustat item seq + txditc - pstkrv) to its market value (Compustat item prcc multiplied by Compustat item csho).

Monthly volatility is defined as the square root of the sum of the squared daily returns (CRSP variable ret) over a month.

Monthly Amihud (2002) illiquidity measure is constructed as follows. We use daily CRSP data (CRSP variables ret, prc, and vol) to calculate the ratio of absolute stock return (multiplied by 1,000,000) to dollar trading volume for each day, after which we average these daily ratios over a month.

\section{$\underline{\text { Short-seller characteristics }}$}

Credible is defined as follows. We examine the arb's prior track record, on the assumption that arbs with a stronger track record are more readily believed when they target a stock. We measure an arb's track record at time $t$ as the rolling mean of the three-month cumulative abnormal returns of all his previous reports (issued at least three months before time $t$, to avoid look-ahead bias) that are independently confirmed. (Confirmatory actions include charges by regulators, earnings restatements, class action lawsuits, trading halts, or delisting notices by exchanges.) We require each arb to have issued at least two reports before we compute a track record. A report issued at time $t$ is coded as more credible if the arb's prior track record produced profits (a negative rolling mean CAR) and as less credible otherwise. Credible is set to missing for reports that raise only (over)valuation concerns without providing new facts previously unknown to investors. 


\section{Figure A1. Sample Reports.}

This figure shows three examples of the front page or executive summary of research reports published by sample arbitrageurs.

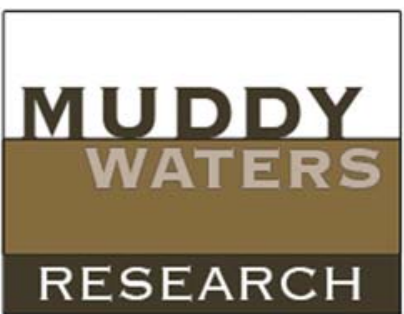

Muddy Waters, LLC

www.muddywatersresearch.com info@muddywatersresearch

Director of Research: Carson C. Block, Esq.

\section{Disclaimer:}

Use of Muddy Waters LLC's research is at your own risk. You should do your own research and due diligence before making any investment decision with respect to securities covered herein. You should assume that as of the publication date of any report, Muddy Waters, LLC (possibly along with or through our members, partners, affiliates, employees, and/or consultants) along with our clients and/or investors has a short position in the stock (and/or options of the stock) covered herein, and therefore stands to realize significant gains in the event that the price of stock declines. Following publication of any report, we intend to continue transacting in the securities covered therein, and we may be long, short, or neutral at any time hereafter regardless of our initial recommendation. This is not an offer to sell or a solicitation of an offer to buy any security, nor shall any security be offered or sold to any person, in any jurisdiction in which such offer would be unlawful under the securities laws of such jurisdiction. To the best of our ability and belief, all information contained herein is accurate and reliable, and has been obtained from public sources we believe to be accurate and reliable, and who are not insiders or connected persons of the stock covered herein or who may otherwise owe any fiduciary duty or duty of confidentiality to the issuer. However, such information is presented "as is," without warranty of any kind - whether express or implied. Muddy Waters, LLC makes no representation, express or implied, as to the accuracy, timeliness, or completeness of any such information or with regard to the results to be obtained from its use. All expressions of opinion are subject to change without notice, and Muddy Waters, LLC does not undertake to update or supplement this report or any of the information contained herein.

\section{Company:}

China Media Express Holdings (CCME)

Industry:

Outdoor Digital Advertising

\section{Recommendation:}

Strong Sell

\section{Estimated Value:}

\section{$\$ 3.54$}

\section{Report Date:}

March 2, 2011

Price:

$\$ 12.27$

Market Cap:

\$420.7 million

Float:

10.2 million

\section{Avg Volume:}

2.8 million
- Muddy Waters, LLC has amassed irrefutable evidence that CCME is a substantial fraud, and that management is engaging in a cover-up replete with further dissemination of fraudulent information.

- We present a recorded telephone conversation that contains an admission that CCME is engaging in securities fraud.

- We document that in the course of rebutting our Report, Chairman Cheng provided fabricated information.

- We present the sales presentation we received in January from the aforementioned salesperson (the "Sales Presentation") that shows CCME has fewer than half of the buses it claims.

- We present a mini-documentary of the largest purported operator - Shanghai Ba Shi - specifically focusing on its inter-city buses and drivers. The film shows that CCME's hardware is not installed on the buses, despite CCME's claim to have had hardware on these buses since at least mid-2008. 


\section{GLAUCUS RESEARCH GROUP MARCH 2011}

\section{UNIVERSAL TRAVEL GROUP (UTA)}

Things gained through unjust fraud are never secure.

$$
\text { - Sophocles }
$$

Disclaimer: As of the publication date of this report, Glaucts Research Grotp and other contributors to this report have short positions in UTA (and/or options of the stock), and therefore stand to realize significant gains if the price of UTA's stock declines. Following publication of this report, Glaucus Research Group and other contributors to this report intend to continue to buy or sell securities issued by UTA and may take long, short or neutral positions at any time hereafter regardless of out initial recommendation. This is not an offer to sell or a solicitation of an offer to buy any security, nor shall any security be offered or sold to any person, in any jurisdiction in which such offer would be tonlawful under the securities laws of such jurisdiction. We have obtained all information set forth in this report from public sources which we believe to be credible. All information set forth in this report is presented "as is" without warranty of any kind, whether express or implied Glaucus Research Group makes no representation, express or implied, as to the accuracy, timeliness, or completeness of any such information or with the results obtained from its use. Glaucus Research Grotp's research, opinions and conclusions should be used at your own risk. All expressions of opinion are subject to change without notice, and Glaucus Research Group does not undertake any duty to tpdate or stipplement this report or any information contained herein.

Company:

Universal Travel

Group (NYSE:

UTA)

Industry: Chinese

Online Travel

Services

Recommendation: Strong Sell

Estimated Value: $\$ 1.00 /$ share

Report Date:

March 8,2011

Price:

S6.28 (as of close on

3/7/11)

Float:

13.2 million

Avg. Volume

300,000 shares/day
- UTA is fabricating its publicly filed financial statements. Its actual underlying business is far smaller than its SEC filings indicate.

- UTA's business model is not credible. For example, UTA claims to have earned $\$ 110$ million in net revenue in the first three quarters of 2010 on an advertising budget of $\$ 247,449$ in the highly competitive leisure travel market. Its competitors spend five to 10 times more on marketing as a percentage of net revenue, casting doubt on the authenticity of UTA's revenue and net income.

- UTA has a deficient and unpopular website, boasts only a minimal brick-and-mortar retail operation and has no kiosks under its control to directly sell to consumers. Yet the company's return on assets and asset turnover figures suggest it is the most efficient company in the leisure travel space, consistently trouncing the competition.

- UTA's website is barely functional (as can be seen in our videos here, here, here, here and here), offers a terrible user experience and receives only a small fraction of the traffic of its Chinese competitors, despite the fact that the company holds itself out as an online travel service provider.

- UTA is a serial capital raiser, repeatedly returning to western investors for cash despite supposedly having, according to its balance sheet, ample cash on hand, which sits unused in an account earning . $36 \%$ in interest per year. UTA is lying about the amount of cash on its balance sheet, as is evidenced by its inexplicably low interest income.

- UTA has destroyed shareholder value through a series of dilutive acquisitions. The company's acquisition targets had much smaller earnings than UTA claimed in its public filings.

- UTA's purported relationship with Agoda, a subsidiary of Priceline.com, is overstated.

- UTA has burned through 4 low-quality auditors and 3 CFOs in 5 years. 


\section{Advanced Battery Technologies, Inc.}

In this report, we present compelling evidence that Advanced Battery Technologies, Inc. ("ABAT" or the "Company") is fabricating its SEC financial statements. We believe that the Company's revenue and profit are highly overstated in its SEC filings. We have created a video where we discuss our findings: Part 1 is here and Part 2 is here. Our evidence includes:

- SAIC filings show that ABAT is reporting significantly lower revenue and profit to the authorities in China. For 2009, SAIC filings showed less than $\$ 2$ million of revenue, compared to $\$ 64$ million in SEC filings.

- ABAT has unreasonably high margins in an established industry with strong competitors. The Company's SEC-reported margins and return on capital are virtually impossible. Out of 106 global battery manufacturers as classified by Bloomberg, ABAT has the highest operating profit margin by a wide margin. When compared to six leading Chinese battery makers, ABAT's operating margin is triple that of its closest competitor and six times that of the median operating margin of the comparable companies.

- Site visits show underutilized facilities lacking in quality control. We hired investigators to visit both the Harbin and Wuxi facilities, and provide photos as well as commentary from our investigators. Our investigators concluded that both facilities produce commodity, low-margin products that are highly unlikely to be generating industry-leading margins or return on capital.

- In December 2010, ABAT announced that it was acquiring a Shenzhen battery maker for $\$ 20$ million. We believe this acquisition is a sham, and that ABAT paid $\$ 20$ million in 2010 for an entity that they had previously bought in 2008 for $\$ 1$ million, but had not disclosed to public investors.

- Confirmation from former customers and partners that the

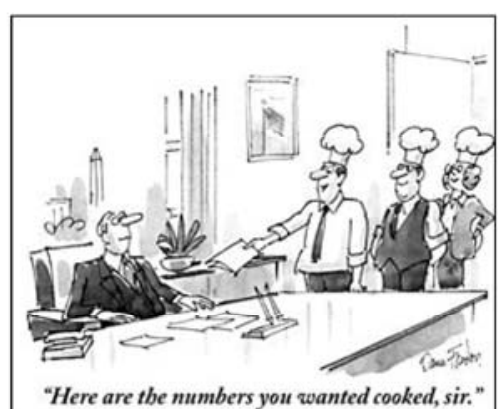

"Here are the numbers you wanted cooked, sir." Company is likely a fraud. After visiting one of ABAT's

plants, one customer called the facility "absolutely the biggest joke l'd ever seen". A recording of the conversation is available here. In another conversation available here and here, a customer said the CEO admitted to hiring an accounting firm "to cook his stock price up".

- Low quality auditors and high turnover. The Company has had 4 auditors in the past 7 years, with no auditor being ranked in the top global 100 auditors at the time of hire.

- Unqualified CFOs and high turnover. A CFO or auditor has resigned at least once a year. The Company's past three CFOs have included: (i) a company insider who has been general manager of the Company's main operating subsidiary since 2004, and is therefore not remotely independent, (ii) a 29-year-old who was formerly VP Finance at China Natural Gas, another fraud, and (iii) a candidate whose primary experience comprised of being a financial adviser at Smith Barney.

- Continuous share dilution through secondary offerings, despite having more than adequate cash reserves. Through repeated share issuances, the Company has grown its outstanding shares from 10.0 million following the 2004 reverse merger to 76.4 million today.

Our estimated fundamental value for ABAT is $\$ 0.00$

Disclaimer: As of the publication date of this report, the Prescience Investment Group, Kerrisdale Capital Management, their affiliates and others that contributed research to this report have short positions in and own options on the stock of the company covered herein (Advanced Battery Technologies, Inc.) and stand to realize gains in the event that the price of the stock declines. Following publication of the report, the authors and contributors may transact in the securities of the company covered herein. The authors of this report have obtained all information herein from sources they believe to be accurate and reliable. However, such information is presented "as is", without warranty of any kind - whether express or implied. The authors of this report make no representation, express or implied, as to the accuracy, timeliness, or completeness of any such information or with regard to the results obtained from its use. All expressions of opinion are subject to change without notice, and the authors do not undertake to update this report or any information contained herein. Please read our full legal disclaimer at the end of the report. 
Figure A2. Examples of Photos and Video Snapshots Contained in Reports

Panel A shows a photo of a target firm's production assets (left) that the report compares to a photo of the more modern looking production assets of the firm's main competitor (right). Panel B shows snapshots of video clips of a different target firm's manufacturing site taken on two different dates (the video on the left was taken three months before the video on the right), both showing an apparent lack of commercial activity of a scale commensurate with the company's financial reports.
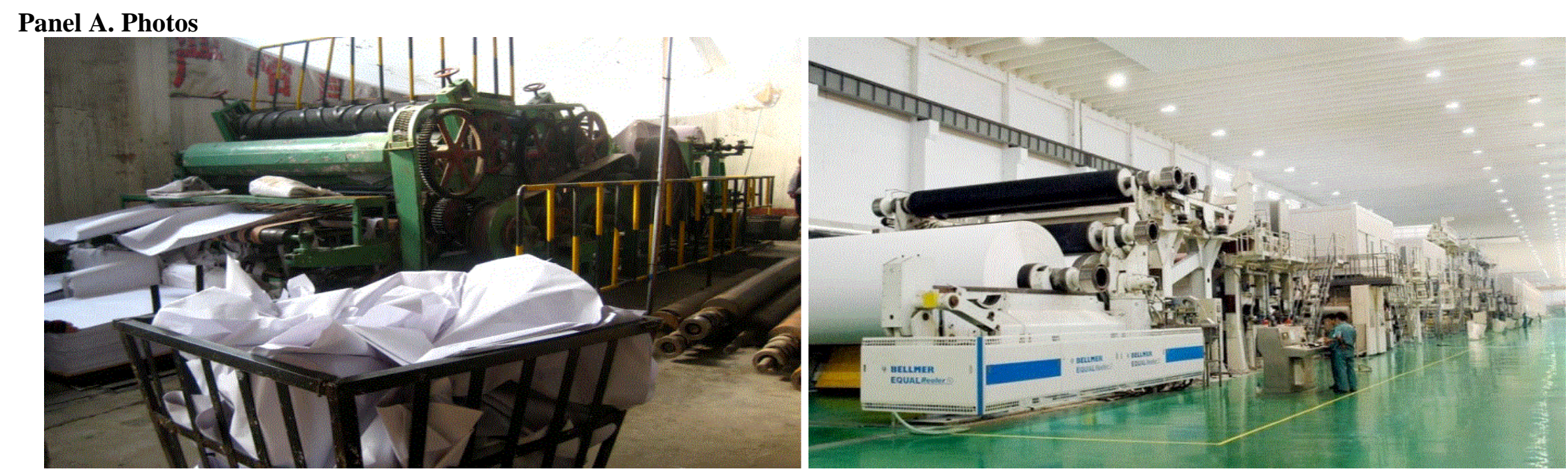

\section{Panel B: Video Snapshots}
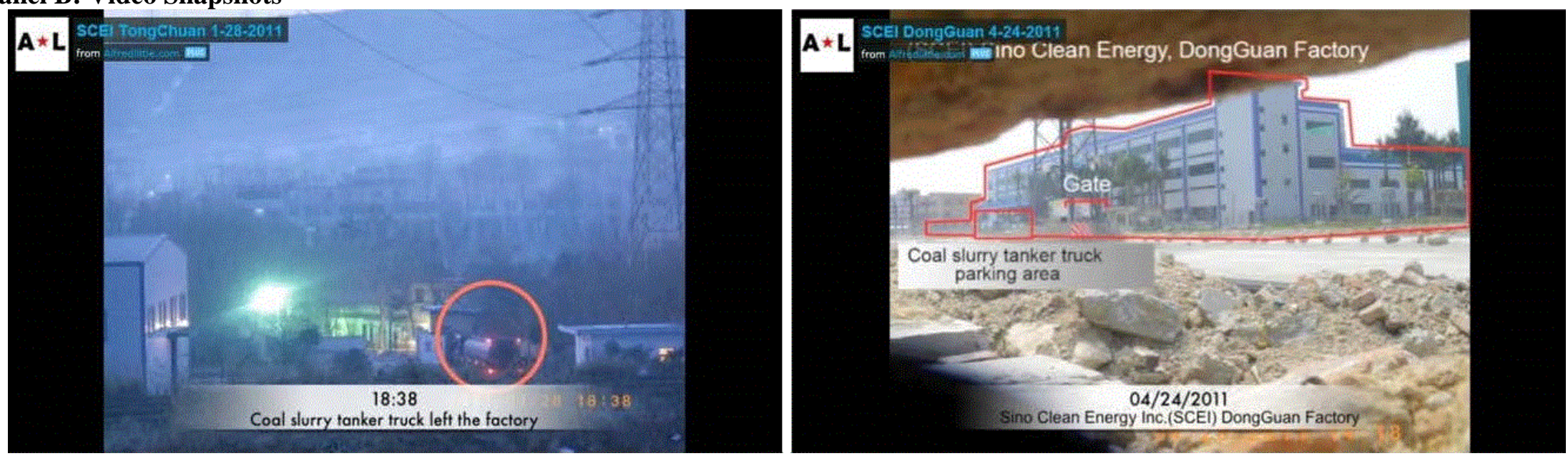


\section{Table A1. Illustrations of Report Titles.}

This table lists 20 examples of report titles used by sample arbitrageurs to attract attention to their reports.

1. “Credibility is like virginity; once you lose it, you can never get it back”, January 24, 2008 (Citron Research)

2. “Arthrocare-Something is rotten in the state of Denmark”, May 2, 2008 (Citron Research)

3. “Emcore... Nothing plus nothing = nothing”, September 9, 2008 (Citron Research)

4. “Citron exposes Apollo’s big dirty secret - All new docs”, March 2, 2009 (Citron Research)

5. “AOB deal questionable even without undisclosed relationship between chairman and seller”, August 5, 2009 (Asensio \& Co.)

6. “SinoCoking: Follow the money!”, March 11, 2010 (Citron Research)

7. “Orient Paper's top supplier: An empty shell owned by ONP's CEO”, August 10, 2010 (Chinese Company Analyst)

8. “China New Borun (BORN)-You are cold busted: Now it is time to come clean”, November 15, 2010 (Citron Research)

9. “A stock only a trading robot could love”, December 28, 2010 (Citron Research)

10. “Another stock only a computer could love: The sequel”, January 24, 2011 (Citron Research)

11. “CCME: The China reverse merger stock that is "too good to be true””, January 30, 2011 (Citron Research)

12. "ChinaCast Education Corporation: Show me the money! Questions to management regarding acquisition \#1”, February 16, 2011 (OLP Global)

13. "Irrefutable evidence of fraud”, March 2, 2011 (Muddy Waters)

14. “China Biotics: The best research you haven't seen”, March 12, 2011 (Citron Research)

15. “DEER: Was the \$22.3 million land use right certificate a forgery?”, March 18, 2011 (Alfred Little)

16. “Sino Clean Energy: Who lied about the weather?”, May 12, 2011(Chimin Sang)

17. “Gulf Resources: Financial claims are beyond reason”, May 19, 2011 (Kerrisdale Capital)

18. “ZAGG: Is it in the covers business, or covering up its real business?”, July 13, 2011 (Citron Research)

19. “Sino Clean Energy is a complete hoax and its shares are worthless", April 28, 2011 (Alfred Little)

20. “The Harbin Land shuffle: A classic bait and switch”, September 23, 2011 (GeoInvesting) 
Table 1. Summary Statistics for the 17 Arbitrageurs.

The sample contains 17 arbitrageurs who target 113 firms with a total of 332 reports over the period from July 2006 to December 2011. Note that there are 118 first reports on 113 target companies, as two arbs released first reports on the same day in the case of five target companies. The table presents, for each of the 17 arbs, summary statistics on the number of reports and target firms as well as post-release returns and profits and the credibility of a report. The year started is the year in which the arb first released a report. (Citron Research and Asensio \& Co. started before the beginning of our sample period.) For variable definitions and details of their construction, see Appendix A.

\begin{tabular}{|c|c|c|c|c|c|c|c|c|}
\hline & $\begin{array}{c}\text { Year } \\
\text { started }\end{array}$ & $\begin{array}{c}\text { Number } \\
\text { of first } \\
\text { reports }\end{array}$ & $\begin{array}{c}\text { Number } \\
\text { of } \\
\text { firms } \\
\text { covered }\end{array}$ & $\begin{array}{c}\text { Total } \\
\text { number } \\
\text { of } \\
\text { reports }\end{array}$ & $\begin{array}{c}\text { Mean } \\
\text { abnormal } \\
\text { return } \\
\text { on report date } \\
\text { (first reports } \\
\text { only) } \\
\% \\
\end{array}$ & $\begin{array}{c}\text { Mean CAR } \\
\text { from report } \\
\text { date to } \\
\text { trading day } \\
60 \\
\text { (first reports } \\
\text { only) } \\
\% \\
\end{array}$ & $\begin{array}{c}\text { Mean } \\
\text { cumulative } \\
\text { abnormal } \\
\text { profit } \\
\text { from trading } \\
\text { day -5 to } \\
\text { trading day } 60 \\
\text { (first reports } \\
\text { only) } \\
\% \\
\end{array}$ & $\begin{array}{l}\text { Fraction of all } \\
\text { reports coded } \\
\text { as "more } \\
\text { credible" } \\
\% \\
\end{array}$ \\
\hline Citron Research & 2001 & 43 & 46 & 106 & -8.0 & -25.5 & 15.8 & 89 \\
\hline Bronte Capital & 2008 & 10 & 12 & 33 & -5.2 & 14.1 & -13.2 & 0 \\
\hline GeoInvesting & 2011 & 8 & 10 & 16 & -11.8 & -39.8 & 40.4 & 100 \\
\hline Alfred Little & 2010 & 7 & 13 & 37 & -19.2 & -13.2 & 13.5 & 100 \\
\hline Ian Bezek & 2009 & 7 & 9 & 14 & 0.5 & -28.7 & 31.7 & 100 \\
\hline Shareholder Watchdog & 2009 & 7 & 8 & 9 & -3.6 & -32.0 & 21.6 & $\mathrm{n} / \mathrm{a}$ \\
\hline Prescience Point & 2011 & 6 & 6 & 6 & -6.8 & -26.6 & 34.3 & 100 \\
\hline Muddy Waters & 2010 & 5 & 6 & 13 & -18.0 & -8.9 & 4.8 & 100 \\
\hline Kerrisdale Capital & 2009 & 5 & 8 & 11 & -7.3 & -19.3 & 28.9 & 100 \\
\hline Asensio \& Co. & 1994 & 4 & 5 & 34 & -9.1 & -58.9 & 61.0 & 100 \\
\hline Chimin Sang & 2009 & 3 & 9 & 18 & -19.9 & -0.1 & 10.1 & 44 \\
\hline Prescience Investment & 2011 & 3 & 4 & 5 & -12.1 & 27.2 & -23.3 & $\mathrm{n} / \mathrm{a}$ \\
\hline Absaroka Capital Management & 2011 & 2 & 4 & 6 & -5.6 & -54.1 & 51.8 & 100 \\
\hline Chinese Company Analyst & 2010 & 2 & 4 & 11 & 0.9 & -15.0 & 15.1 & 100 \\
\hline The Forensic Factor & 2011 & 2 & 2 & 6 & -10.8 & -29.7 & 13.7 & 0 \\
\hline Glaucus Research & 2011 & 2 & 3 & 4 & -4.9 & 3.1 & 4.1 & 100 \\
\hline OLP Global & 2010 & 2 & 2 & 3 & -4.0 & -9.3 & 11.4 & $\mathrm{n} / \mathrm{a}$ \\
\hline Average (across the 17 arbs) & & 7 & 9 & 20 & -8.5 & -18.6 & 18.9 & 81 \\
\hline
\end{tabular}




\section{Table 2. Summary Statistics of Target Firms.}

The sample contains 113 firms targeted by 17 arbs over the period from July 2006 to December 2011. The table reports summary statistics of key firm characteristics measured as of the most recent calendar month before the release of the first report on the target. For each characteristic, the final column reports the percentile rank of the average target firm in the CRSP universe one month before the report release date. For variable definitions and details of their construction, see Appendix A.

\begin{tabular}{|c|c|c|c|c|c|c|}
\hline & Mean & Std. dev. & $\begin{array}{c}\text { Lower } \\
\text { quartile }\end{array}$ & Median & $\begin{array}{c}\text { Upper } \\
\text { quartile }\end{array}$ & $\begin{array}{c}\text { Percentile } \\
\text { in CRSP } \\
\text { universe }\end{array}$ \\
\hline \multicolumn{7}{|l|}{ Firm characteristics } \\
\hline market capitalization (\$ million) & 979.2 & 2243.9 & 158.7 & 312.2 & 776.0 & 0.54 \\
\hline book/market ratio & 0.40 & 0.29 & 0.18 & 0.32 & 0.61 & 0.30 \\
\hline daily turnover (\%) & 2.35 & 4.77 & 0.51 & 1.00 & 1.93 & 0.71 \\
\hline monthly Amihud illiquidity measure & 0.04 & 0.14 & 0.00 & 0.01 & 0.02 & 0.43 \\
\hline monthly volatility (\%) & 7.44 & 15.71 & 1.86 & 4.01 & 7.00 & 0.78 \\
\hline \multicolumn{7}{|l|}{ Shorting conditions } \\
\hline daily shorting fee (\%) & 0.04 & 0.06 & 0.00 & 0.01 & 0.05 & 0.76 \\
\hline lendable (\%) & 4.85 & 7.05 & 0.22 & 1.41 & 6.25 & 0.39 \\
\hline put-call implied volatility ratio & 1.15 & 0.25 & 1.02 & 1.07 & 1.19 & 0.69 \\
\hline
\end{tabular}




\section{Table 3. Information Discovery and Report Contents.}

The table provides a breakdown of the 332 sample reports according to whether they convey the results of information production (i.e., the discovery of facts previously unknown to investors) or whether they result from information processing (i.e., the reinterpretation of already known data). The former type of report contains concerns regarding financial reporting, governance, or "red flag" events. Panel A presents a frequency breakdown of the main concerns based on our reading of the reports. The latter type of report, tabulated in Panel B, essentially claims a stock is overvalued based on a different interpretation of known data.

Fraction

Panel A: Reports producing new information $(\mathrm{N}=\mathbf{2 8 5})$

Concerns regarding financial reporting or governance

Accounting irregularities

Questionable performance

Misrepresentation of financials

0.23

Questionable balance sheet

0.11

Other misrepresentation

0.32

Disclosure problems

0.24

Management

0.20

Auditor quality

0.15

Internal control

0.12

$\underline{\text { Red flag events }}$

Questionable business practice $\quad 0.28$

Self-dealing/related party transactions $\quad 0.22$

Questionable acquisition $\quad 0.18$

Questionable insider selling $\quad 0.06$

Questionable capital raising $\quad 0.05$

Outstanding legal actions $\quad 0.03$

Questionable stock repurchase $\quad 0.01$

Panel B: Reports reinterpreting known information $(\mathrm{N}=47)$

$\begin{array}{ll}\text { Concerns regarding valuation } & 0.14\end{array}$ 


\section{Table 4. Cumulative Abnormal Returns Around Report Releases.}

This table reports Fama-French/momentum four-factor cumulative abnormal returns (CARs) of target firms measured over different event windows leading up to the release of a report and for the report-day itself. Panel A focuses on first reports. Panel B focuses on follow-on reports. For variable definitions and details of their construction, see Appendix A. We perform a two-sided $t$-test for mean CARs, a Wilcoxon test for median CARs, and generalized $Z$ test for the number of negative CARs, and use ${ }^{* * *}, * *$, and $*$ to denote significance at the $1 \%$, $5 \%$, and $10 \%$ level, respectively.

\begin{tabular}{cccc}
\hline & \multicolumn{3}{c}{ Cumulate abnormal returns (in \%) } \\
\cline { 2 - 4 } & mean & median & positive:negative \\
\hline
\end{tabular}

\section{Panel A: First reports}

trading days -20 to -6

trading days -5 to -1

$4.43^{* * *}$

$-0.33$

$-3.51^{* *}$

52:54

trading day 0 (report date)

$-1.31^{*}$

$-5.20^{* * *}$

42:64

$-8.18^{* * *}$

$24: 82^{* * * *}$

Panel B: Follow-on reports

trading day 0 (report date)

$-2.59^{* * *}$

$-1.13^{* * *}$

$75: 120^{* * *}$ 


\section{Table 5. Abnormal Returns and Trading by Type of Report and Shorting Cost.}

This table reports average abnormal return and trading statistics on the report date in subsamples sorted by the credibility of the report (in Panel A), the nature of the information discovery (in Panel B), and the cost of shorting as measured using either shorting fees (in Panel C) or the supply of lendable stock available for borrowing (in Panel D). Since the credibility-based subsamples in Panel A include follow-up reports for the same target, we also report abnormal returns on the day the first report is released. Panels B, C, and D include only first reports. Panels C and D focus on the 91 targets for which data on shorting fees and the supply of lendable stock are available as of the baseline period (one month before the release of the first report). For variable definitions and details of their construction, see Appendix A. We use ${ }^{* * *},{ }^{* *}$, and * to denote significance at the $1 \%, 5 \%$, and $10 \%$ level (twosided), respectively.

\begin{tabular}{|c|c|c|c|}
\hline Panel A: & $\begin{array}{c}\text { More } \\
\text { credible } \\
(\mathrm{N}=167) \\
\end{array}$ & $\begin{array}{c}\text { Less } \\
\text { credible } \\
(\mathrm{N}=36) \\
\end{array}$ & $\begin{array}{c}\text { Difference } \\
\text { in means }\end{array}$ \\
\hline $\begin{array}{l}\text { abnormal return on report date (first reports only) } \\
\text { abnormal return on report date (all reports) } \\
\text { abnormal turnover } \\
\text { abnormal long trades/shares outstanding }\end{array}$ & $\begin{array}{r}-0.125^{* * *} \\
-0.058^{* * *} \\
1.189^{* * *} \\
1.398^{* * *}\end{array}$ & $\begin{array}{l}-0.045 \\
-0.021^{*} \\
0.893^{* * *} \\
0.919^{* * *}\end{array}$ & $\begin{array}{c}-0.079^{*} \\
-0.037^{*} \\
0.300 \\
0.479^{*}\end{array}$ \\
\hline Panel B: & $\begin{array}{c}\text { Information } \\
\text { production } \\
(\mathrm{N}=86) \\
\end{array}$ & $\begin{array}{c}\text { Information } \\
\text { processing } \\
(\mathrm{N}=27) \\
\end{array}$ & $\begin{array}{c}\text { Difference } \\
\text { in means }\end{array}$ \\
\hline $\begin{array}{l}\text { abnormal return on report date } \\
\text { abnormal turnover } \\
\text { abnormal long trades/shares outstanding }\end{array}$ & $\begin{array}{r}-0.102^{* * *} \\
1.676^{* * *} \\
1.843^{* * *}\end{array}$ & $\begin{array}{l}-0.017 \\
1.086^{* * *} \\
0.980^{* * *}\end{array}$ & $\begin{array}{l}-0.085^{* * *} \\
0.590^{* *} \\
0.863^{* *}\end{array}$ \\
\hline Panel C: & $\begin{array}{c}\text { High } \\
\text { shorting fee } \\
(\mathrm{N}=46)\end{array}$ & $\begin{array}{c}\text { Low } \\
\text { shorting fee } \\
(\mathrm{N}=45)\end{array}$ & $\begin{array}{c}\text { Difference } \\
\text { in means }\end{array}$ \\
\hline $\begin{array}{l}\text { abnormal return on report date } \\
\text { abnormal turnover } \\
\text { abnormal long trades/shares outstanding }\end{array}$ & $\begin{array}{r}-0.072^{* * *} \\
1.514^{* * *} \\
1.645^{* * *}\end{array}$ & $\begin{array}{r}-0.086^{* * *} \\
1.487^{* * *} \\
1.633^{* * *}\end{array}$ & $\begin{array}{l}0.013 \\
0.028 \\
0.012\end{array}$ \\
\hline Panel D: & $\begin{array}{c}\text { Low } \\
\text { lendable } \\
(\mathrm{N}=45)\end{array}$ & $\begin{array}{c}\text { High } \\
\text { lendable } \\
(\mathrm{N}=46) \\
\end{array}$ & $\begin{array}{c}\text { Difference } \\
\text { in means } \\
\end{array}$ \\
\hline $\begin{array}{l}\text { abnormal return on report date } \\
\text { abnormal turnover } \\
\text { abnormal long trades/shares outstanding }\end{array}$ & $\begin{array}{r}-0.102^{* * *} \\
1.720^{* * *} \\
1.819^{* * *}\end{array}$ & $\begin{array}{r}-0.058^{* * *} \\
1.286^{* * *} \\
1.463^{* * *}\end{array}$ & $\begin{array}{r}-0.043^{*} \\
0.435 \\
0.356\end{array}$ \\
\hline
\end{tabular}

